\title{
Byerne i Slesvig ca. 1830-1914
}

af HANS SCHULTZ HANSEN

I Sønderjyske årbøger 2006 skrev afdelingsleder Lars N. Henningsen, Studieafdelingen ved Dansk Centralbibliotek for Sydslesvig, om de slesvigske byer ca. 1700-1830. Her følger arkivar og forskningsleder Hans Schultz Hansen fra Landsarkivet for Senderjylland op på denne artikel med en undersøgelse af den slesvigske byudvikling ca. 1830-1914.

1800-tallets by kan betragtes under flere forskellige synsvinkler. Den formelle, juridiske definition beskriver byen som en sluttet bebyggelse, der var adskilt fra de omgivende landområder, og som udgjorde en selvstændig kommune med et udviklet selvstyre, ofte tillige en selvstændig retskreds. Dertil kom indtil 1867 byboernes særlige monopol på at drive borgerlig næring indenfor en given radius (forbudsmile) og andre privilegier som ret til at holde marked og oprette lav samt byboernes fritagelse for landmilitærtjenesten. I 1800-tallet blev den enkelte bys status efterhånden reguleret ved generel lovgivning.

Man kan også se på 1800-tallets by som et økonomisk kraftfelt. For det første var den et centralsted for højt specialiserede håndværksfag og serviceerhverv, hvor landbefolkningen kunne få dækket de behov for produkter og ydelser, der ikke kunne tilfredsstilles lokalt, og selv afsætte produkter. For det andet virkede byen som formidler af vareudveksling over store afstande primært i kraft af søfarten. Og for det tredje var byen et industricenter; i 1800-tallet lokaliseredes stadig flere fabrikker $\mathrm{i}$ byen, hvor kapital, teknisk viden og arbejdskraft fandtes. Desuden kan 1800-tallets by forstås som et udgangspunkt for den statslige magtudøvelse med domiciler for myndigheder og militær, og som kulturcentrum takket være f.eks. en domkirke, et gymnasium eller en videregående uddannelsesinstitution.

Oplagt er det endelig at se 1800-talsbyen som en befolkningskoncentration, hvor et stort og stadigt stigende antal mennesker boede sammen på et snævert område i modsætning til den spredte bebyggelse og mere stillestående befolkningsudvikling på landet.

De forskellige byfunktioner og en stærkt varierende befolkningsudvikling gav i 1800-tallet byerne ret forskellige profiler og udviklingstræk. Nye typer af byer skød op ved siden af de eksisterende, og der 
etableredes et byhierarki, hvori de enkelte byer fandt deres plads. Denne artikel vil belyse de slesvigske 1800-talsbyer med udgangspunkt i de forskellige synsvinkler og skitsere de vigtigste udviklingslinjer i forholdet byerne imellem. Den vil tillige vurdere de slesvigske byer i forhold til byerne nord for Kongeåen og syd for Ejderen. Derimod vil byernes indre udvikling, d.v.s. social- og husstandsstruktur, kvartersdannelse og infrastruktur med gader, forsynings- og kloakvæsen m.m. ikke blive berørt, skønt der også på disse områder var tale om store forandringer.

\section{Bytyper med særstatus - købstæder og flækker}

I modsætning til kongeriget Danmark fandtes der i hertugdømmet Slesvig og i nabohertugdømmet Holsten ikke én, men to typer af byer, som i kraft af selvstændig administration og forrettigheder skilte sig ud fra de omliggende landdistrikter: Foruden købstæderne var det flækkerne. ${ }^{1}$ En sådan todeling af de bymæssige bebyggelser er imidlertid ikke noget særsyn i mellemeuropæisk og britisk byhistorie.

Købstæderne var med et udtryk fra tidens førende slesvigske jurist Niels Falck »kommuner af første rang «. De var ligestillet med hertugdømmernes amter og store landskaber og helt udskilt fra disse; undtagelser herfra var alene Tønning og Garding, som var kommunalt forenet med landskabet Ejdersted. Indtil 1848 stod købstæderne direkte under den kongelige statholder og den slesvigske overret, fra 1834 den slesvig-holstenske provinsialregering. Dog blev de stedlige amtmænd 1808 indsat som »overdirektører« for alle købstæder med undtagelse af Flensborg, og ved den slesvigske borgerkrigs ophør i 1850 blev amtmændene $i$ almindelighed kontrol-, mellem- og politiinstans for købstæderne; undtaget herfra blev igen Flensborg, der fik sin egen overpræsident. ${ }^{2}$ I preussisk tid fra 1867 til 1920 hørte købstæderne under kredsene og havde landråderne som overøvrighed, ligesom de valgte repræsentanter til kredsdagene. Dog opnåede Flensborg som den eneste by i Slesvig i 1889 den eftertragtede status som kreisfreie Stadt (kredsfri by) direkte under regeringen i Slesvig.

Før 1867 udgjorde købstæderne selvstændige retskredse adskilt fra de omkringliggende herreder og med magistraten som dømmende myndighed. En undtagelse herfra var Ærøskøbing, som siden 1773 udgjorde én retskreds sammen med resten af Ærø. I 1867 blev købstæderne lagt ind under de nye preussiske amtsretter, hvorved de mistede deres traditionelle selvstændige retsvæsen. Også købstæder- 


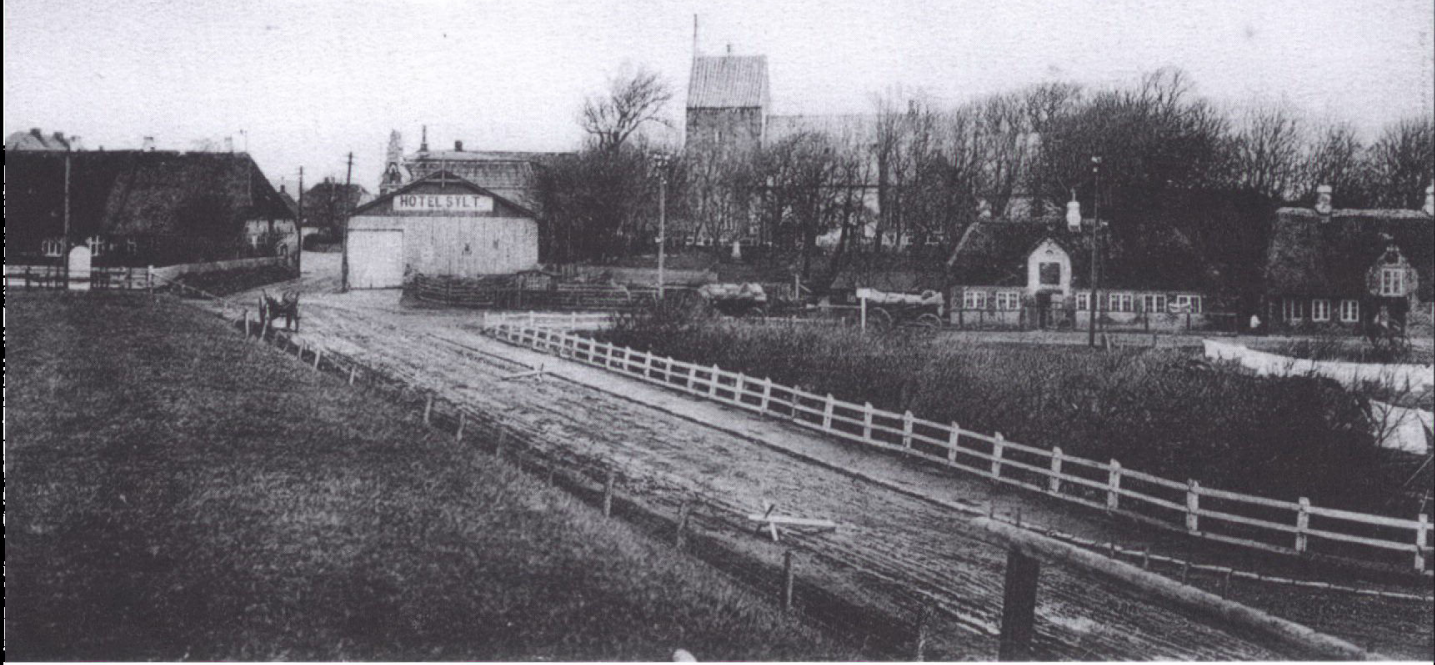

De slesvigske flakker var en bytype, som skød sig ind mellem købstæder og landsbyer. Der fandtes $i$ alt en halv snes af disse småbyer, som ofte havde et landligt prag over sig. Det gialdt ikke mindst for Højer med mange garde og husmandssteder $i$ den traditionelle vestslesvigske byggestil liggende inde $i$ byen. På dette postkort for 1914 indvarsles de moderne tider af Hotel Sylt, eftersom Hojer dengang var udskibningssted for trafikken til Sild. Museum Sønderjylland. ISL - Lokalhistorie.

nes gamle monopol på udøvelse af borgerlig næring inden for deres forbudsmile samt privilegiet til at oprette lav blev ophævet efter indlemmelsen i Preussen; det skete med loven om næringsfrihed i 1867. Endelig bortfaldt et tredje gammelt købstadsprivilegium, fritagelsen for landmilitærtjenesten, med indførelsen af den almindelige preussiske værnepligt i 1867. Tilbage af købstædernes særstatus blev efter 1867 deres særlige kommunale selvstyre, som blev reguleret med den slesvig-holstenske Städteordnung (købstadslov) fra 1869.

Flækkerne var gennemgående mindre end hertugdømmets købstæder, men på størrelse med flere af de små købstæder i kongeriget. Flækkerne blev af Falck betegnet som »kommuner af anden rang«. Det betød, at de var underordnet amter og store landskaber, men sidestillet med herreder, birker og små landskaber, og at de adskilt fra disse udgjorde selvstændige kommuner med egen styrelse. Som købstæderne havde de før 1867 ret til at udøve borgerlig næring og ret til, at deres håndværkere kunne organisere sig i lav, ligesom de indbyggere, der ikke havde landbrug som hovednæring, var fri for landmilitærtjenesten. 
Indførelsen af den preussiske kredsordning i 1867 og den slesvigholstenske købstadslov i 1869 gav anledning til en præcisering af, hvilke bebyggelser der kunne anses for selvstændige byer. ${ }^{3}$ Som købstæder regnedes de gamle slesvigske købstæder fra før 1864. Dog var Ærøskøbing gledet ud af rækken, fordi Ærø i 1864 var forblevet ved Danmark, og Burg på Femern måtte også anses som tabt for Slesvig, efter at øen i 1867 var blevet lagt ind under den holstenske kreds Oldenburg. Af de 11 tilbageværende slesvigske købstæder lå de seks på østkysten: Haderslev, Aabenraa, Sønderborg, Flensborg, Slesvig by og Egernførde. På vestkysten fandtes fem: Tønder, Husum, Tønning, Garding og Frederikstad.

Der blev også i 1867 afklaret, at 10 slesvigske byer havde status som flækker: Christiansfeld var brødremenighedens by, Nordborg, Augustenborg og Glücksborg var tidligere residensbyer for hertuger af de sønderborgske linjer, Løgumkloster var efter Reformationen centrum i Løgumkloster amt, mens Kappel og Arnæs ved Slien, Højer og Bredsted samt Wyk på Før primært skyldte søfart, handel og håndværk deres oprindelse. Før 1864 hørte også Marstal på $Æ$ Erø ubestridt til blandt flækkerne. Den udskiltes af Rise sogn 1737/38, men fik først en formel flækkeordning i 1861 med forbillede i Kappels fra $1846 .{ }^{4}$ Allerede tre år senere udgik Marstal af de slesvigske flækkers række, da Ærø som nævnt i 1864 forblev ved Danmark. ${ }^{5}$

Retshistoriske og topografiske forfattere regnede før 1864 yderligere en håndfuld bymæssige bebyggelser med blandt de slesvigske flækker. Falck anså i 1825 Oldenswort i Ejdersted for en flække, men ifølge August von Baggesen, Johs. von Schröder og J.P. Trap havde byen mistet sine flækkerettigheder $\mathrm{i}$ år 1800 . Som den eneste regnede Falck det lille søbatteri Frederiksort over for Kiel i Dänischwohld som flække. Baggesen, von Schröder og Trap benævnte desuden Gråsten som flække. Baggesen regnede desuden Svavsted med blandt flækkerne, men han anførte, at den var gået tilbage og at den i det statistiske tabelværk ikke regnedes blandt de steder, der udøvede byerhverv. Von Schröder kaldte uden forbehold Svavsted for en flække, mens Trap henførte den til "de ikke laugsberettigede flækker«. Petersdorf på Femern betegnede Baggesen som en kirkeby med flækkerettighed; Trap nævnte tilsvarende, at byen havde "nogle flækkerettigheder «. Andre bebyggelser kaldte Baggesen »flækkelignende»: Læk i Kær herred, Tating i Ejdersted og Sønder Stapel i landskabet Stapelholm. ${ }^{6}$

Ingen af de her nævnte steder opnåede status som flække i 1867. De 
fleste af dem fik nok mere betegnelsen flække hæftet på sig i kraft af deres størrelse og erhvervsforhold end på grundlag af ubestridte flækkeprivilegier. Tilbage står, at flækkerne nedadtil var mindre skarpt afgrænset end købstæderne, i det mindste i samtidens bevidsthed.

\section{Lovgivning om byerne}

Selvstyret i de slesvigske købstæder beroede indtil 1869 ikke på en moderne fælles købstadslov som kongerigets fra 1837, men på gamle og individuelle bestemmelser for de enkelte byer.

Kun få reformer gennemførtes. Egernførde fik i 1832 et »reglement for byens økonomiske forvaltning «. Magistrat og deputeretkollegium måtte ikke længere være selvsupplerende. De menige magistratsmedlemmer skulle vælges for livstid af magistrat og deputeretkollegium i fællesskab, deputeretkollegiet for seks år ad gangen af alle husejere med borgerret. Denne ændring i demokratisk retning var mere en "reform fra oven « fra det Slesvig-Holsten-Lauenborgske Kancelli end en imødekommelse af ønsker fra borgerskabet. ${ }^{7}$ Derimod stillede borgerskabet i Haderslev, Sønderborg og Slesvig i 1831 i kølvandet på Lornsenrøret og stænderforordningen liberalt inspirerede krav om reformer i bystyret, og i 1832 fulgte Flensborg efter. Kun i Flensborg gav bevægelsen resultat. Byen fik i 1833 et »normativ«, der brød købmændenes gamle monopol på pladserne i magistrat og deputeretkollegium og afskaffede nyudpegning af medlemmerne ved selvsupplering. I stedet fik alle med borgerret og grundejendom $\mathbf{i}$ byen valgret til deputeretkollegiet. De deputerede skulle vælges for 12 år ad gangen. 12 deputerede skulle fremover sammen med magistraten vælge nye magistratsmedlemmer. Førsteborgmester, politimester og bysekretær skulle dog stadig udpeges af kongen. ${ }^{8}$

Videre reformer blev standset af regeringen med henvisning til, at en ny købstadslov var undervejs. Et udkast blev forelagt de slesvigske stænder i 1844, men druknede dér i de nationale modsætninger. Den provisoriske slesvig-holstenske regerings meget liberale købstadslov fra 1848 fik aldrig praktisk betydning i Slesvig og blev ophævet i $1850 .{ }^{9}$ Efter 1850 var det genetablerede danske styre betænkelig ved reformer i demokratisk retning, der kunne styrke det slesvig-holstenske element $i$ hertugdømmet Slesvig, som netop stod stærkest $i$ byerne. Holsten fik en byordning i 1854, Slesvig derimod ingen.

Forst med den slesvig-holstenske Städteordnung fra 1869 fik de 


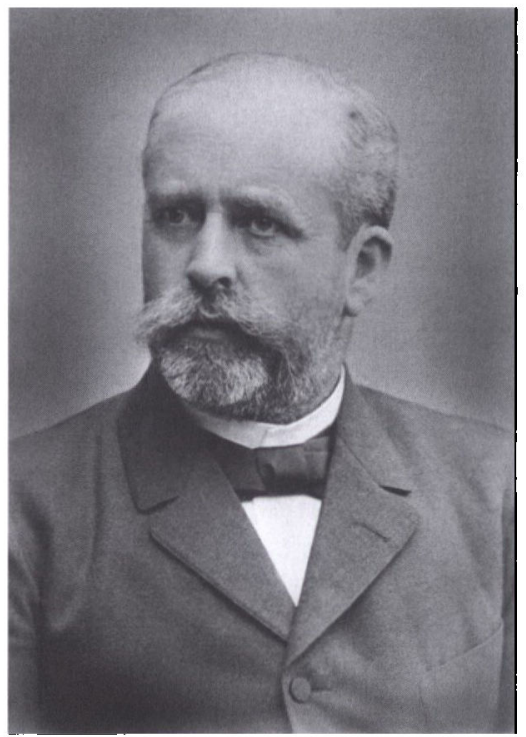

Den slesvig-holstenske kabstadslov fra 1869 gav borgerskabet ret til at vælge borgmesteren for tolv år ad gangen. Dog skulle valget godkendes af regeringen $i$ Slesvig. I Sonderborg valgte borgerne $i$ 1883 den hamborgske Ludwig Ferdinand Moraht, der kom fra borgntesterposten $i$ den lille by Heiligenhafen $i$ Østholsten. Han sogte imidlertid bort allerede $i 1890$ efter uoverensstemmelser med deputeretkollegiet $i$ jernbanesagen. Han var typisk for de borgmestre, der ikke havde nogen særlig tilknytning til den by, de blev sat $i$ spidsen for. Foto: Museum Sonderjylland. ISL - Lokalhistorie.

slesvigske byer langt om længe et fælles lovgrundlag. ${ }^{10}$ Borgerret tilkom herefter indbyggere i byen, der havde selvstændig husstand og betalte kommuneskat samt enten havde eget hus eller udøvede stedfast borgerlig næring eller havde en indkomst over en vis minimumsgrænse (census), som skulle fastsættes i den lokale styrelsesvedtægt (Ortsstatut). Byens udøvende myndighed var magistraten, som bestod af borgmesteren, dennes stedfortræder og flere rådmænd. Den blev valgt af borgerne; borgmesteren og lønnede magistratsmedlemmer for tolv år, de øvrige for seks. Valget af borgmester og stedfortræder krævede godkendelse hos regeringen i Slesvig, for byer med over 10.000 indbyggere hos den preussiske konge, d.v.s. indenrigsministeriet i Berlin. Borgerne valgte også en borgerrepræsentation (Stadtverordneten-Versammlung) på mellem seks og 30 medlemmer og med en funktionsperiode på seks år. Borgerrepræsentationen valgte sin egen formand (Vorsteher, Bürgerworthalter). Borgerrepræsentationen skulle give sit besyv med ved alle byanliggender, som ikke udtrykkeligt kunne afgøres af magistraten alene. Til behandling af stående opgaver kunne der nedsættes kommissioner med medlemmer fra magistrat og borgerrepræsentation.

Städteordnung indeholdt også bestemmelser om en forenklet byforfatning (einfachere Städte-Verfassung), som kunne indføres i de mindre 
byer og i flækkerne. Her smeltede magistrat og borgerrepræsentation sammen, således at bystyret blev ledet af en borgmester, der på én gang var borgmester, magistrat og borgerrepræsentationsformand. Borgmesteren kunne være lønnet og valgtes så af borgerne for tolv år, eller ulønnet og vælges for seks år. Borgmesteren skulle også her godkendes af regeringen i Slesvig. Ved sin side fik han to-tre ulønnede rådmænd valgt for tre, fire eller seks år; de kunne samtidig være medlemmer af borgerrepræsentationen. Denne bestod ud over borgmesteren af firetolv medlemmer. I byer med forenklet byforfatning kunne minimumsindkomsten for borgerskab sættes lavere end i de andre byer.

Flertallet af de slesvigske købstæder antog den slesvig-holstenske Städteordnungs »fulde« byforfatning, mens Frederikstad og Tønning (samt Burg) sammen med flækkerne valgte den »forenklede« version. Städteordnung fra 1869 gav imidlertid mulighed for, at flækker kunne skifte til købstadsstatus. De sydslesvigske flækker benyttede sig flittigt heraf: Kappel allerede i 1870, Bredsted og Glücksborg i 1900 og Wyk i 1910 (Arnæs først i 1934). Den finere status fik næppe praktisk betydning for byernes udvikling. Badebyen Vesterland på Sild tog springet direkte fra landkommune til købstad i 1905. De nordslesvigske flækker holdt derimod fast på deres status også efter Genforeningen i 1920 og helt frem til kommunalreformen i $1970 .{ }^{11}$

Det kommunale selvstyre i købstæderne blev også efter de forskellige reformer domineret af købmændene. Skønt købmændenes monopol på bystyret i Flensborg blev ophævet, udgjorde de i perioden 18331868 stadig $57 \%$ af de deputerede, mens fabrikanter udgiorde $21 \%$. Håndværkerne var repræsenteret med $20 \%$, gæstgiverne og høkerne med 3\%. Efter indførelsen af den slesvig-holstenske byordning af 1869 og indtil indførelsen af almindelig og lige valgret for alle indbyggere i 1919 faldt købmændenes andel af de deputerede til $48 \%$ og fabrikanternes til 11\%. Håndværkernes andel forblev stort set uændret med $21 \%$, mens den for gæstgivere og høkere faldt til $1 \%$. Nye grupper var udøvere af liberale erhverv som advokater, læger m.m. med $11 \%$ og embedsmænd og funktionærer med $8 \%$. Derimod udelukkede valgretsbestemmelsernes census, at de lavere sociale lag kunne vinde indflydelse på bystyret, hvilket efter århundredskiftet navnlig blev en torn i øjet på Flensborgs socialdemokrater, der udgjorde flertallet af byens vælgere ved rigsdagsvalgene, men kun formåede at få ganske få valgt ind i borgerrepræsentationen. Skønt den slesvig-holstenske byordning havde gjort kredsen af vælgere bredere, var deltagelse i det kommunale selv- 
styre altså stadig reserveret et velhavende mindretal. Det blev først ændret efter revolutionen i $1918 .{ }^{12}$ Ikke kun socialdemokrater, men også venstreliberale vendte sig imod de snævre valgretsbestemmelser. Blandt disse var borgmesteren i Husum Lothar Schücking, som derfor fik en disciplinærsag på halsen, der ganske vist "kun « resulterede i en bøde. Men presset fik ham alligevel til at træde tilbage. ${ }^{13}$

I de andre byer var købmændenes dominans ikke så udtalt som i Flensborg. I Haderslev udgjorde købmænd, apotekere, fabrikanter, korn- og tømmerhandlere 39\% af de deputerede i perioden 1800-1890. Bagere, slagtere og håndværksmestre udgjorde 35\%, gæstgivere, møllere, bryggere og brændere $15 \%$, embedsmænd, akademikere og liberale erhvervsudøvere $7 \%$, andre erhverv og personer med manglende erhvervsangivelse $4 \%$. Opgjort på delperioder viste købmændenes andel en faldende tendens, især efter 1869. Det samme gjaldt gæstgiverne m.m. og håndværkerne, mens embedsmænd m.m. vandt stærkt frem, ligesom i Flensborg. ${ }^{14}$ I Sønderborg udgjorde købmændene 26 ud af de i alt 86 medlemmer af borgerrepræsentationen i perioden 1870-1910. Derudover var der 13 håndværkere, mens resten var advokater, læger, rektorer, møllere og fabrikanter. ${ }^{15}$ Også her synes den nye byelite at have vundet betydelig indflydelse.

\section{Slesvigske centralsteder ca. 1800 og 1860}

Geografen Klaus Greve fra universitetet i Bonn har undersøgt de slesvigske bebyggelser omkring 1800 og i 1860 med udgangspunkt i geografen Walter Christallers centralstedsteori fra 1933. ${ }^{16}$ Denne teori giver mulighed for at placere de enkelte bebyggelser i et hierarki, hvor deres rang bestemmes af antallet og arten af de centrale funktioner, de hver især rummer; det kan være specialiserede håndværk, butikker o.l. Greve opererer således med tre niveauer af centralitet: I, II og III, hvor I repræsenterer steder med flest centrale funktioner (»hochzentrale Orte«), III med færrest (»niederzentrale Orte«) og II en mellemgruppe ("mittelzentrale Orte«). Til gruppe I hører byer med et helt eller næsten fuldstændigt udbud af centralstedsfunktioner, som de normalt findes i en købstad. Gruppe III udgøres af den typiske slesvigske kirkelandsby, hvor grundlæggende behov for varer og tjenesteydelser kunne dækkes af de lokale smede, hjulmagere, næringsmiddel- og beklædningshåndværkere, kromænd og præster. Denne gruppe vil ikke være så interessant i vor sammenhæng. Det er til 

rurger. Hertil hørte som mindstemål flækkerne Kappel og Løgumkloster samt landsbyen Sønderstapel i landskabet Stapelholm. Sandsynligvis var der flere i gruppe II, som blot ikke kan identificeres på grund af hullerne i kildematerialet. Mon ikke resten af flækkerne tilhørte dette trin? Sønderstapel må ud fra denne tilgang betegnes som en rural by, d.v.s. en større bebyggelse på landet, der rummede vigtige centralstedsfunktioner, men ikke havde formel status som by.

For 1860 undersøgte Klaus Greve 24 centrale funktioner, som han rangordnede med optikere, fotografer og instrumenthandlere på de tre øverste og skomagere, smede og skræddere på de tre nederste pladser. På ny befandt samtlige købstæder sig i den fornemme ende af niveau I, denne gang med Frederikstad og Tønder som undtagelser. Til gengæld var Garding og Kappel rykket op i forreste række. I den knap så fine ende af niveau I lå nu Frederikstad og Tønder sammen med Bredsted, Højer og Løgumkloster. I alt var der i 186015 byer i niveau I mod 13 omkring år 1800.

I niveau II var der derimod sket en betragtelig udvidelse, idet der nu var 13 bebyggelser her mod tre omkring 1800 . Her fandtes flækkerne Nordborg, Augustenborg, Christiansfeld og Glücksborg, men ud over Sønderstapel nu også Gram, Gråsten, Keitum på Sild, Læk, Pelworm ny sogn, Nibøl-Dedsbøl, Skærbæk og Tating i Ejdersted. I hvert fald de fire første og de to sidste kan anses for rurale byer. Udviklingen fra 1800 til 1860 kan sammenfattes i nedenstående skema.

Centralsteder i Slesvig omkring 1800 og 1860

\begin{tabular}{l|l|l}
\hline & 1800 & 1860 \\
\hline $\begin{array}{l}\text { Gruppe I } \\
\text { (købstæder) }\end{array}$ & $\begin{array}{l}\text { Haderslev, Aabenraa, } \\
\text { Sønderborg, Flensborg, } \\
\text { Slesvig, Egernførde, } \\
\text { Tønder, Husum, Tønning, } \\
\text { Frederikstad }\end{array}$ & $\begin{array}{l}\text { Haderslev, Aabenraa, } \\
\text { Sønderborg, Flensborg, } \\
\text { Slesvig, Egernførde, } \\
\text { Husum, Tønning, Garding, } \\
\text { Kappel }\end{array}$ \\
\hline $\begin{array}{l}\text { Gruppe IA } \\
\text { (småkøbstæder, } \\
\text { flækker) }\end{array}$ & $\begin{array}{l}\text { Garding, Nordborg, } \\
\text { Bredsted }\end{array}$ & $\begin{array}{l}\text { Tønder, Frederikstad, } \\
\text { Bredsted, Højer, } \\
\text { Løgumkloster }\end{array}$ \\
$\begin{array}{l}\text { Gruppe II } \\
\text { (flækker, rurale } \\
\text { byer) }\end{array}$ & Kappel, Løgumkloster, & $\begin{array}{l}\text { Nordborg, Augustenborg, } \\
\text { Christiansfeld, Glücksborg, } \\
\text { Sønderstapel }\end{array}$ \\
& & $\begin{array}{l}\text { Gråsten, Keitum, Læk, } \\
\text { Pelworm ny sogn, Nibøl- } \\
\text { Dedsbøl, Skærbæk, Tating }\end{array}$ \\
\hline
\end{tabular}




\section{Nye centralsteder efter 1864 - stationsbyerne}

Desværre findes ingen tilsvarende undersøgelser af centralstederne efter 1860. Det er imidlertid almindelig kendt, at det slesvigske bysystem fra 1860'erne og frem til 1914 blev udvidet med en helt ny type af centralsteder: stationsbyerne. ${ }^{17} \mathrm{I} \mathrm{kraft}$ af de mange jernbaneanlæg blev stationsbyerne efter 1864 den altdominerende hovedtype på den rurale by. Stationsbyer af alle størrelser blev så udbredt, at tidligere tiders dybe skel mellem land og by blev udvisket. Som det kan konstateres af periodens mange fotografier af de større stationsbyers huse og gader, flyttede byen som bebyggelsestype ud på landet, og dens livsformer kom meget nærmere på landboernes dagligdag. Topografen Henning Oldekop tilskrev i 1906 såvel Skærbæk som Toftlund »städtischer Charakter«, og både Gråsten, Sønder Brarup og Gettorf fik betegnelsen »fleckenartig “ ${ }^{18}$ Stationsbyerne opnåede ingen administrativ særstatus som købstæder eller flækker, men forblev landkommuner.

Stationsbydannelsen skete i tilknytning til anlæggelsen af først det statslige og siden det kredskommunale jernbanenet, d.v.s. amtsbanerne. ${ }^{19}$ Den første slesvigske jernbane fra 1854 forbandt Flensborg og Tønning via Husum. Fra Øster Ørsted fik banen samme år via Rendsborg forbindelse til det holstenske jernbanenet fra 1844/45, og i 1858 blev Slesvig by koblet på med en kort stikbane fra Klosterkro. I årene 1864-66 forlængedes banen fra Flensborg nordover til Kolding. Der blev herfra 1866-68 lagt stikbaner til Tønder, Aabenraa og Haderslev udgående h.h.v. fra Tinglev, Rødekro og Vojens. I Sydslesvig blev sporene i 1869 lagt om, således at linjen Øster Ørsted-Klosterkro blev nedlagt og erstattet med en forbindelse fra Slesvig til Jybæk, der samtidig fik forbindelse til Flensborg-Tønningbanen. Flensborg fik i 1881 via Egernførde en forbindelse med Kiel. På vestkysten blev der i 1887 åbnet en bane Frederikstad-Ribe. Herfra blev der i 1888 skabt forbindelse fra Lindholm til Sporskifte ved Flensborg og fra Bredebro til Løgumkloster samt i 1892 fra Tønder til Højer Sluse. I Ejdersted blev der samme år bygget en bane fra Tønning til Garding. I 1901 var det endelig Sønderborgs tur til som den sidste slesvigske købstad at opnå togforbindelse. Det skete både fra Padborg og Tinglev på den østlige længdebane. Linjerne herfra mødtes i Tørsbøl, hvorfra banen via Gråsten gik mod øst til Sønderborg. Fra denne bane anlagdes i 1910 en stikbane fra Vester Sottrup til Skelde på Broagerland. Den sidste af de normalsporede jernbaner i Slesvig før 1914 blev lagt i 1910 og for- 
bandt Husum med Rendsborg via Nørrestapel. Da var anlægget af smalsporede kredsbaner forlængst begyndt med banen Slesvig-Sønder Brarup som den første i 1883. Navnlig i kredsene Slesvig, Flensborg land, Aabenraa, Sønderborg og Haderslev blev der i de kommende årtier anlagt mange af disse småbaner.

Det var ikke så meget alle disse baneforbindelser i sig selv, der skabte stationsbyerne. Fra 1867 var der næringsfrihed, så intet håndværk længere var bundet til byerne. Landbefolkningens stigende velstand fremmede arbejdsdelingen. Afviklingen af den traditionelle hjemmeproduktion på gårdene gav plads til flere bagere, slagtere, skomagere og træskomagere, og byggeriet af nye stuehuse og staldbygninger skabte efterspørgsel efter murere, tømrere og malere, mens en forfinet møbelsmag gav beskæftigelse til flere kunstdrejere og snedkere. Landbrugets intensivering fra $1880^{\prime}$ erne skabte øgede behov for fabrikation og reparation af redskaber og maskiner. Smede, hjulmagere og sadelmagere kom i vækst, og flere små maskinfabrikker skød op. Forarbejdningen af landbrugsproduktionen rykkede også ud fra gårdene, mest gennemgribende ved oprettelsen af andelsmejerier. Der blev også plads til flere handlende. Behovet for kunstgødning og foderkager fremmede sammen med afsætningen af det stigende høstudbytte grovvarehandelen. De større besætninger af kvæg og svin gav næring til flere handelsmænd, som købte levende dyr op til videresalg sydpå. Det øgede forbrug af luksusvarer som kaffe og tobak og en række dagligvarer betød et stigende antal høkere, og da bønderne fik bedre tid og råd til at gå til kros, voksede antallet af gæstgiverier. De mere påholdende kunne sætte deres penge i det voksende antal banker og sparekasser. En meget stor del af de virksomheder, som den stigende velstand og intensivering gav grundlag for, blev lokaliseret nær de nye jernbanestationer, hvorfra transporten af personer og gods til og fra egnen nemt og effektivt kunne foregå. ${ }^{20}$

Et eksempel på, hvad en stor stationsby kunne rumme af centrale funktioner og småindustri efter århundredskiftet, er Sønder Brarup med læge, apotek, to banker, elværk, dampsavværk, møbelsnedkeri med 12-14 arbejdere, seks små snedkerier, fem bygmestre, forskellige håndværk, vind- og dampmølle, mejeri, seks kroer, manufaktur-, kolonial og foderstofhandel, cykelforretning og fattiggård. Der kunne også være administrative centralfunktioner som i Toftlund med amtsret, skattekasse og fattiggård - foruden svendeherberg, kreditfor- 


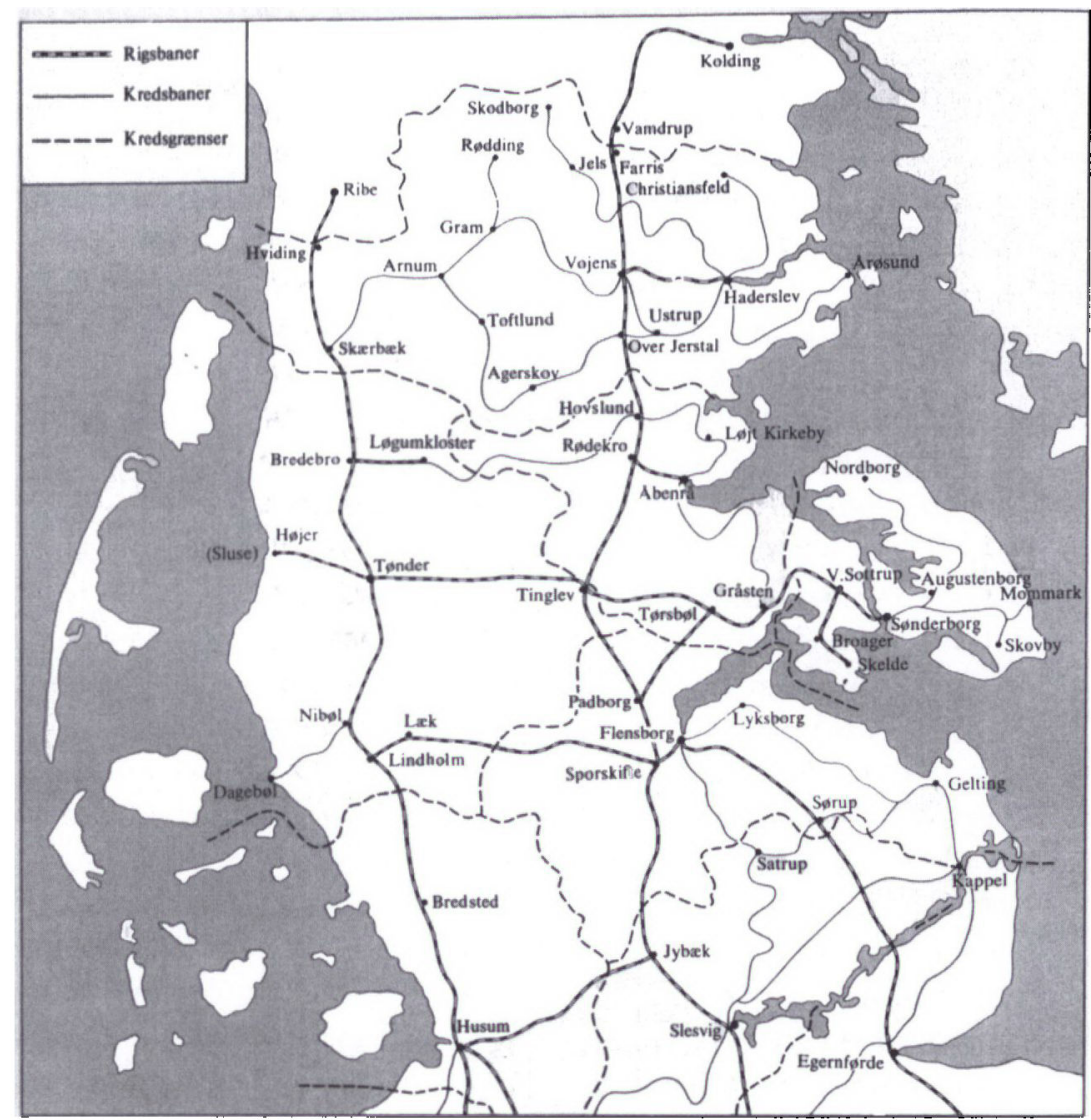

Kortet over jernbanenettet $i 1910$ viser det fuldt udbyggede jernbanenet fra den preussiske tid med bide de normalsporede rigsbaner og de smalsporede kredsbaner. Fra Sønderjylland Historisk Billedbog 1864-1920.

ening, læge, dyrlæge, apotek, elværk samt et større antal butikker og »alle slags håndværk «. Selv en noget mindre stationsby som Sommersted rummede 11 handlende, 14 håndværkere og tre kroer. Af samme størrelse var Jybæk med fire kroer, en mølle, et mejeri, spare- og lånekasse, fire købmænd, smedje, 10 håndværkere, et savværk og et uldspinderi. $^{21}$

Stationsbydannelsen betød fremkomsten af nye rurale byer. Flere af de ældre rurale byer som Skærbæk, Gram, Gråsten, Læk og Nibøl fik i kraft af deres beliggenhed ved de nye jernbaner plads blandt de største stationsbyer. Samtidig voksede andre større stationsbysamfund frem 
på landet. For lokaliseringen af disse nye rurale byer synes flere faktorer at have haft betydning. For det første var der afstanden til de etablerede købstæder og flækker. Det falder i øjnene, at der i det traditionelt købstads- og flækkeløse Haderslev Vesteramt blev plads til fire betydelige stationsbyer; udover Skærbæk var det Gram, Rødding og Toftlund. ${ }^{22}$ De to sidstnævnte byer var gamle herredstingsteder og Toftlund et gammelt vejcentrum. I Angel og Sundeved var afstanden til de eksisterende byer ikke så stor som i Haderslev Vesteramt, men til gengæld var befolkningstætheden desto større. ${ }^{23}$ I Angel skød tre stationsbyer frem i midten af trekanten Flensborg-Slesvig-Kappel, her nævnt efter størrelse: Sønder Brarup, Satrup og Sørup. I Sundeved blev Gråsten mellem Aabenraa og Sønderborg en stor stationsby. Derimod var der ikke plads til større stationsbyer på Als, hvor Sønderborg, Augustenborg og Nordborg var veletablerede centralsteder.

Betydningen af landbrugets intensivering for stationsbydannelsen sættes i relief ved en sammenligning med Vestslesvig. Her forblev landbruget ekstensivt; i marskområderne langs den sydslesvigske vestkyst blev det tilmed yderligere ekstensivt med studegræsning som den helt dominerende driftsform og med en mærkbar befolkningsnedgang til følge. Her var der ikke så megen dynamik tilstede, og derfor var der en ret beskeden vækst i Nibøl og Læk, skønt begge lå $\mathrm{i}$ bekvem afstand til Tønder og Bredsted. ${ }^{24}$

Det går næppe an helt at afskrive jernbanerne selvstændig betydning for stationsbyernes udvikling. Der var en særlig dynamik i knudepunkterne på den østlige længdebane, som vist kun kan tilskrives jernbanens kombinerede forbindelser til de gamle købstæder og til den store verden. Sommersted, Vojens, Rødekro, Tinglev og Jybæk var her frontløbere med mere end en fordobling af befolkningstallet, skønt disse stationsbyer tildels lå $\mathrm{i}$ det tyndere befolkede midtland med et ikke specielt intensivt landbrug og $i$ en behersket afstand fra østkystens købstæder. ${ }^{25}$ Vojens og Rødekro opstod tilmed på den bare mark, mens stationen $\mathrm{i}$ Tinglev oprindelig lå ensomt på en eng $1 \frac{1}{2} \mathrm{~km}$ øst for den oprindelige landsby omkring kirken. Her som i flere andre tilsvarende tilfælde voksede stationsby og kirkeby først efterhånden sammen.

\section{Byerne som magt- og kulturcentre}

Klaus Greves undersøgelser af centralstederne 1800 og 1860 medtager alene centralstedsfunktioner fra den private sektor. Landboerne måtte 
imidlertid også begive sig til bys, når de skulle i kontakt med højere myndigheder. $^{26}$

Slesvig var indtil 1850 hertugdømmets regeringsby. Her havde kongens statholder, overretten, overkonsistoriet, landretten og fra 1834 den slesvig-holstenske provinsialregering hjemme på Gottorp Slot. Her mødtes fra 1836 den slesvigske stænderforsamling hvert andet år på byens rådhus. Endvidere husede Slesvig en mængde over- og landretsadvokater. Byen var også hjemsted for den gejstlige administration med generalsuperintendenten for Slesvig stift. Byen rummede endelig to store sociale institutioner: døvstummeinstituttet og dårekisten, oprettet henholdsvis 1810 og 1819.

Efter det slesvig-holstenske nederlag i 1850 blev byen straffet for sine udpræget tyske sympatier, da stænderforsamlingen flyttedes til den loyale by Flensborg, hvor også den nye slesvigske appellationsret, regeringskommissæren, den slesvigske centralkasse, en række embeder indenfor medicinal-, vej- og jernbanevæen m.m. samt fra 1854 tillige den slesvigske biskop fik til huse. Fra 1844 fandtes her en filial af den danske Nationalbank. Herligheden varede dog kun kort; efter indlemmelsen i Preussen i 1867 genvandt Slesvig by sin gamle ære og værdighed, da den kongelige regering for hertugdømmerne blev placeret her i den nye massive regeringsbygning »den røde elefant« nær Gottorp Slot. I årene 1879-1917 havde desuden overpræsidenten for provinsen Slesvig-Holsten sæde her. Også generalsuperintendenten fandt tilbage til Slesvig.

Indenfor administration havde Slesvig - og mellem krigene Flensborg - centralstedsfunktioner på et højere niveau end de andre byer. Som de fleste andre købstæder havde Slesvig og Flensborg tillige myndigheder på regionalt niveau. Før 1864 var det typisk administrationen over byernes opland med amtmand, amtsforvalter, husfoged og branddirektør. Desuden boede adskillige herredsfogder og tingskrivere og dermed ligestillede embedsmænd i købstæderne. Dertil kom etaterne med toldere og postembedsmænd. Før 1864 fandtes der amtsadministrationer i Haderslev, Aabenraa, Tønder, Flensborg, Slesvig, Husum og Burg samt indtil 1850 tillige i Sønderborg. Efter 1867 blev de fleste købstæder centre for den preussiske kredsforvaltning med landråden i spidsen: Haderslev, Aabenraa, Tønder, Flensborg, Husum, Tønning, Slesvig og Egernførde. Landråden over Sønderborg kreds havde i begyndelsen domicil i Augustenborg, men flyttede siden til Sønderborg. Det var kun småkøbstæderne Garding og Frederikstad, som aldrig fik amts- eller kredsadministration. 


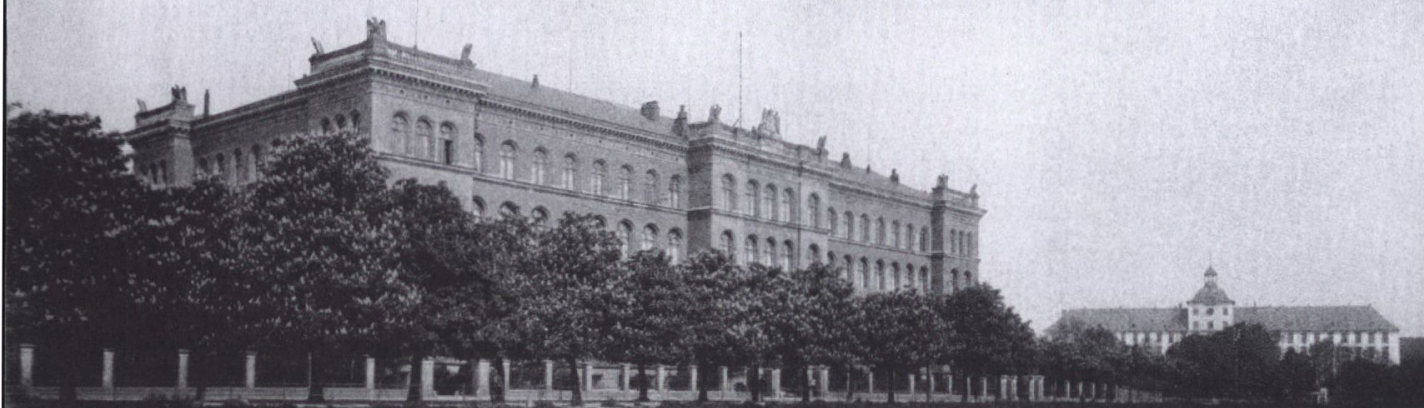

Slesvig oar, med undtagelse af tiden mellem de slesvigske krige 1850-64, hertugdommet Slesvigs administrationscentrum. I baggrunden ses det gamle magtcentrum, Gottorp Slot, hor for 1848 den kongelige statholder, overretten og provinsialregeringen havde til huse. I forgrunden ses "Den rode Elefant", der var ogenavnet pa den nye og massive regeringsbygning, som blev opfort $i$ ärene 1876-79 efter landsdelens indlemmelse $i$ Preussen $i$ 1867. Foto: Arkivet ved Dansk Centralbibliotek for Sydslesvig.

Landboerne måtte også aftjene deres værnepligt i de slesvigske garnisonsbyer. ${ }^{27}$ Militærets lokalisering gav disse byer status som magtcentre og var tillige af stor betydning for de handlende. Før 1848 fandtes hertugdømmernes generalkommando og hovedparten af tropperne i Rendsborg, men garnisoner fandtes også i Slesvig by samt i Haderslev og Husum (de to sidstnævnte steder indtil 1842). I 1850 fik den slesvigske generalkommando hjemme i Flensborg, der nu også fik en større garnison. Den militære udbygning i Flensborg skete dog ikke på bekostning af Slesvig, der beholdt sin garnison, og Egernførde blev også garnisonsby, fordi troppernes tilstedeværelse var påkrævet ved hertugdømmets sydgrænse. Af samme grund havde Husum garnison 1850-54. Efter indlemmelsen i Preussen flyttede generalkommandoen til Altona, men bortset herfra fik det nye styres oprustning mærkbare følger for flere af de slesvigske byer. Haderslev blev igen garnisonsby 1867-77 og permanent fra 1888. For Aabenraa og August- 
enborg var herligheden forbigående, begrænset til henholdsvis 186788 og 1864-76. Sønderborg derimod var fæstningsby i årene 1869-84 med en stor garnison, og også herefter var der kaserne i Sønderborg. I 1907 fik byen i forbindelse med den tyske flådeoprustning en betydelig marinestation. Flensborg nød tilsvarende godt af oprustningen. På Duborg byggedes i 1874 en stor infanterikaserne. Fra 1902 fandtes en torpedoskole ved Mørvig, og i 1910 indviede kejseren den store marineofficersskole her. I Slesvig by rykkede tysk militær ind på Gottorp Slot, der allerede i dansk tid var indrettet til kaserne. Moltkekasernen blev opført i 1892. Ved kysten ud for Egernførde blev der i 1913 indrettet et torpedoindskydningsanlæg. Frederiksort nord for Kiel bestod fortsat som en kystbefæstning.

Fredeligere manifestationer af byerne som centralsteder var undervisningsinstitutionerne. ${ }^{28}$ Slesvig havde ikke sit eget universitet; det lå lige uden for hertugdømmets grænser i Kiel, som var begge hertugdømmers akademiske centrum. I Slesvig fandtes flere lærerseminarer. Det ældste blev oprettet i 1788 i Tønder; hertil kom seminarer i Egernførde i 1858 og i Haderslev i 1884 samt lærerindeseminarer på Augustenborg slot i 1878 og i Slesvig i 1895. Lærde skoler fandtes fra gammel tid i Slesvig, Flensborg, Haderslev og Husum.

Det var i langt de fleste tilfælde også fra købstæderne, at aviserne udgik. ${ }^{29}$ De første levedygtige aviser opstod i slutningen af 1700-tallet eller de første tre årtier af 1800-tallet i form af ugentlige, upolitiske »intelligensblade«: Lyna i Haderslev 1797, Allgemeines Wochenblatt i Aabenraa 1826, Sonderburger Wochenblatt ca. 1815 med dansk udgave fra 1832, Tondernsches Intelligenzblatt 1813, Flensburger Wochenblatt 1788, Schleswigsche wöchentliche Unterhaltungen 1789 (til 1810), Schleswiger Intelligenzblatt 1812, Eckernförder Wochenblatt 1814, Husumer Wochenblatt 1813, Der Ditmarscher und Eiderstedter Bote i Frederikstad 1802, Eiderstedter Wochenblatt i Tønning 1842. Fra slutningen af $1830^{\prime}$ erne kom politiske blade som Dannevirke i Haderslev 1838, Apenrader Ugeblad 1839, Flensburger Zeitung 1840. De politiske omvæltninger 1848-50 og 1864-67 bragte en del kortvarige bladeventyr, som ikke skal nævnes her. Efter 1864 fandtes mindst ét tysk-borgerligt blad i købstæderne og danske aviser i Haderslev, Aabenraa, Sønderborg og Flensborg (med aflægger i Tønder). I nogle flækker og store stationsbyer var forsøg på selvstændige avisgrundlæggelser i reglen forgæves, og de blade, som disse byer lagde navn til, var for det meste aflæggere af købstadsaviser. Løgumkloster havde en længere årrække egen avis. 
1800-tallets politisering af den slesvigske befolkning udgik således mest fra købstæderne. Det gjaldt også de tidlige politiske foreningsdannelser fra 1840'erne som Den slesvigske Forening og Den slesvigholstenske patriotiske Forening, der begge havde hjemsted i Haderslev.

Medicinalvæsnets fremgang styrkede også købstædernes centralfunktioner med sygehuse, og læger og apoteker var med til at give også flækker og rurale byer status. I 1880 fandtes der almene medicinske sygehuse i Haderslev (to), Gram, Aabenraa, Sønderborg, Tønder, Flensborg (to), Kappel, Slesvig, Egernførde og Husum. Hertugdømmets store psykiatriske sygehus befandt sig som nævnt i Slesvig by. I Wyk fandtes et børnesygehus. ${ }^{30}$

\section{Byerne som søfarts- og industricentre}

Byerne var traditionelt formidlere af vareudvekslingen over store afstande, og hertil kom i 1800-tallet deres betydning som hjemsteder for den fremvoksende industri.

En målestok for byernes betydning som formidlere af vareudveksling er deres skibstonnage. ${ }^{31}$ De største søfartsbyer var Flensborg, Aabenraa og Sønderborg samt indtil 1864 Marstal. I 1806 lå Flensborg i spidsen med over 15.000 kommercelæster fulgt af Sønderborg med knap 2.500 og Aabenraa med 2.100 samt Marstal med 1.400; resten af byerne havde under 1.000. Den folgende periode var imidlertid en nedgangsperiode for søfarten i Flensborg, og i 1832 havde Aabenraa halet pænt ind med godt $3.100 \mathrm{KL}$ mod Flensborgs knap 5.400. Sønderborg var gået bag af dansen med godt $1.100 \mathrm{KL}$ og overhalet af Marstal med 1.400-1.500. De øvrige byer holdt sig stadig under 1.000. De følgende tre årtier gav generelt fremgang for slesvigsk søfart bortset fra Flensborg, hvor nedgangen fortsatte. I 1862 var tonnagen her skrumpet ind til $4.900 \mathrm{KL}$, mens Aabenraa nu havde førerpositionen med 5.600; det var dog ikke så meget Aabenraas egen fjernhandel som byens rolle som underleverandør af skibstonnage til storkøbmændene i Hamborg, der var baggrunden for denne tilvækst. Marstal havde fortsat ekspanderet til godt $3.600 \mathrm{KL}$, mens Sønderborg lå på fjerdepladsen med 2.600. Yderligere havde i 1862 Haderslev, Ærøskøbing, Arnæs og Kappel sneget sig op over de 1.000 KL; Ærøskøbing lå højst med godt 1.300 .

Efter 1864 faldt den ærøske søfart ud af den slesvigske sammen- 


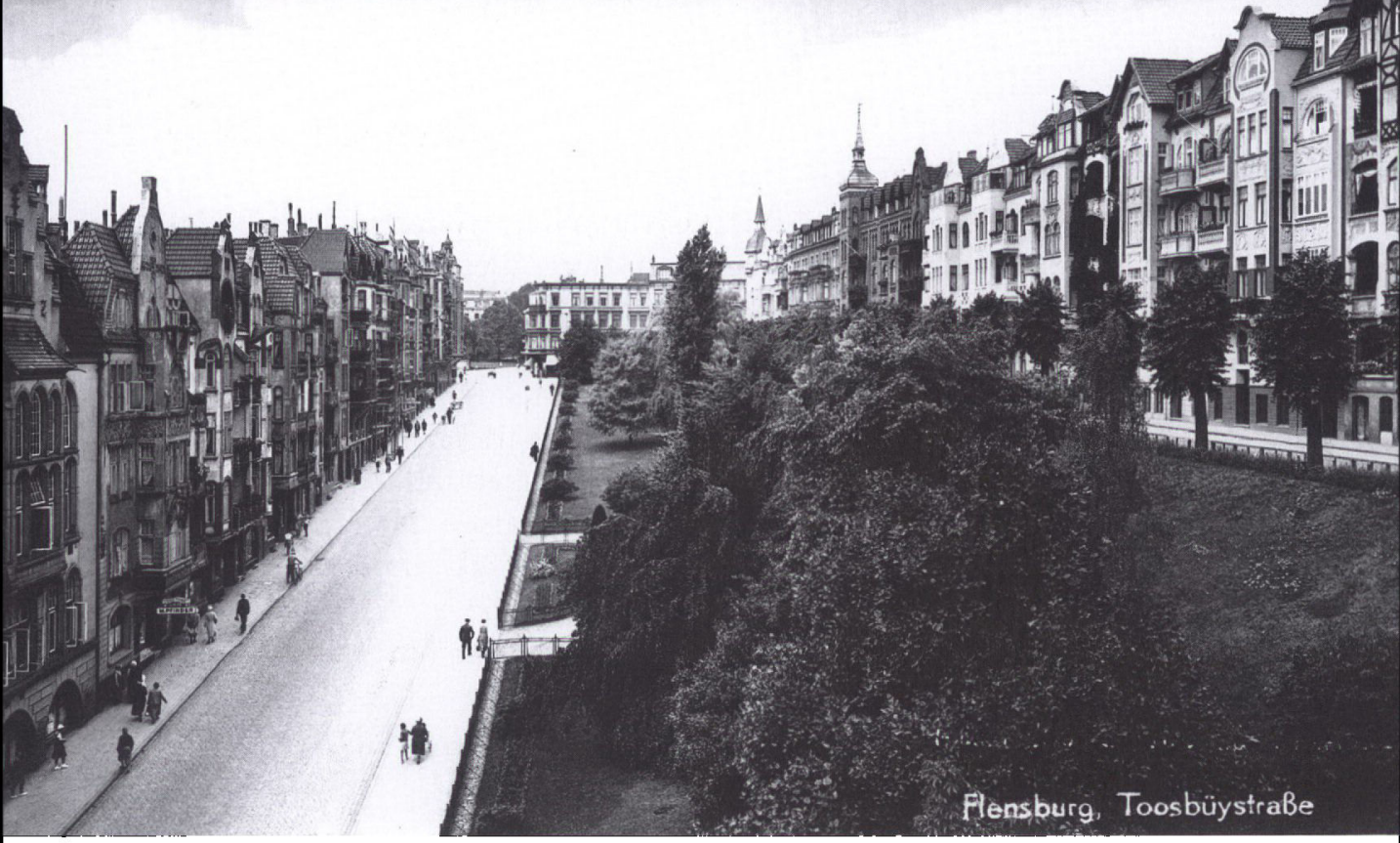

Takket være befolkningsvæksten som folge industrialiseringen fik Flensborg mere og mere præg af storby med nye kvarterer anlagt efter de store linjer. Det blev især synligt med anlagget af Toosbüystrasse fra omkring århundredskiftet $i$ den tidstypiske jugendstil. Her blev der bygget flotte huse med store lejligheder for byens velstående middelklasse. Th. Thomsen foto $i$ Arkivet ved Dansk Centralbibliotek for Sydslesvig.

hæng, og opgørelsesmetoden ændredes fra KL til nettoregistertons. Endnu i 1873 var Aabenraa hertugdømmets førende søfartsby med 9.000 NRT fulgt af Flensborg med 7.000 og Sønderborg med 3.000; de øvrige byer havde alle under 800 , Tønning dog 1.200 . Endnu i 1880 lå Aabenraa i spidsen, men Aabenraaredernes stædige fastholden ved sejlskibene fortrængte $\mathrm{i}$ løbet af de næste syv år byens søfart til andenpladsen; i 1887 var Aabenraas tonnage overfløjet af Flensborgs, og de følgende årtier bestyrkede yderligere denne bys førerstilling i den slesvigske søfart. I 1913 var Flensborgs tonnage 70.000 NRT mod Aabenraas 16.500 og Sønderborgs 1.500; resten af byerne inkl. Tønning havde under 800 NRT.

Flensborg løb altså på det nærmeste med det hele efter 1864. Den samme markante tendens viste sig indenfor industrien. ${ }^{32}$ Opgjort $i$ antallet af ansatte i fremstillingsvirksomheder med mindst seks ansatte var Flensborg igennem hele perioden fra 1800 til 1914 den forende industriby, når der ses bort fra kniplingsfremstillingen, hvor kræmmerne $\mathrm{i}$ Tønder havde mange piger $\mathrm{i}$ de omgivende landområder $\mathrm{i}$ deres brød. I de første årtier var industriens betydning imidlertid ringe, men fra 1840 'erne blev industrialiseringen en mærkbar faktor i 
de slesvigske byers udvikling. Da den toppede foreløbigt i 1857, var der næsten 850 industriarbejdere i Flensborg, mens Slesvig kom ind på andenpladsen med over 390 og Haderslev på tredjepladsen med godt 260. Alle andre byer havde færre end 200. Efter 1864 ramtes de fleste slesvigske byer af industriel tilbagegang, mens Flensborgs industrialisering efter en kortvarig tilbagegang for alvor tog fart fra 1870 'erne. I år 1900 havde byen over 3.500 industriarbejdere. Slesvig og Haderslev lå stadig på anden- og tredjepladsen med 450 og lige over 370, nu tæet fulgt af Tønning med knap 340. Resten af byerne havde stadig under 200 industriarbejdere.

Flensborgs stærke fremgang på bekostning af de øvrige slesvigske byer inden for to centrale byerhverv kunne ikke undgå at påvirke byernes befolkningstal og deres indbyrdes størrelsesforhold.

\section{Byerne som befolkningskoncentrationer}

De slesvigske købstæders og flækkers befolkning voksede i løbet af 1800-tallet med 100.000 mennesker. Byernes andel af hertugdømmets befolkning steg i samme periode fra en femtedel til en tredjedel. En betydelig urbanisering fandt altså sted, og den bliver ikke mindre, når stationsbyerne lægges oveni. En nærmere betragtning viser imidlertid, at vækstforløbet ikke var helt jævnt: ${ }^{33}$

Den slesvigske bybefolkning 1803-1910

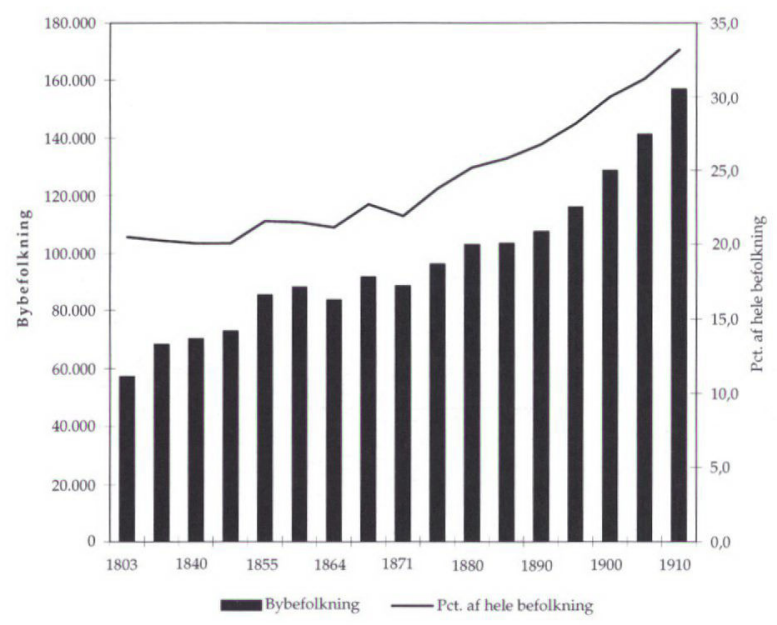


Urbaniseringen i Slesvig kan inddeles i følgende faser: ${ }^{34}$

1803-1845: Selv om bybefolkningen voksede absolut, var der ikke tale om nogen urbanisering, da byernes andel af den samlede befolkning var konstant eller svagt faldende på grund af en tilsvarende eller større vækst i landbefolkningen.

1845-1871: En svag og usikker urbanisering, hvor bybefolkningens andel blot øgedes med to procent. Udviklingen præges af et par mindre tilbageslag absolut såvel som relativt i 1864 og 1871 .

1871-1890: En jævn urbanisering med absolut vækst i bybefolkningen og i byernes andel af den samlede befolkning, der øges med fire procent.

1890-1910: En accelereret urbanisering, der navnlig viser sig ved en tiltagende absolut vækst, men også ved en øget andel af den samlede befolkning med syv procent.

Byernes samlede indbyggertal og andel af befolkning $i$ procent

(Hertugdømmerne inkl. flækker)
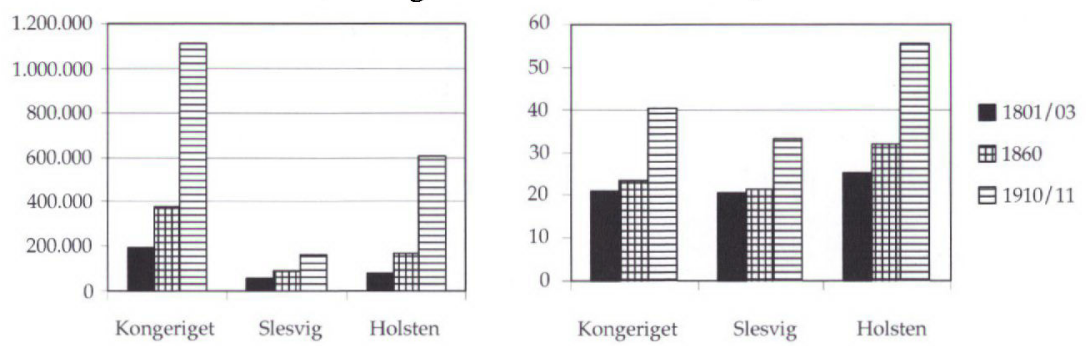

En sammenligning med den kongerigske og holstenske byudvikling viser, at de slesvigske byer trods deres tilvækst i løbet af 1800 -tallet sakkede agterud: ${ }^{35}$

Allerede 1801/03-1860 kneb det for Slesvig med at holde trit med kongerigets urbanisering. I den preussiske tid blev det gamle hertugdømme helt sat af kapløbet. Holsten lå hele tiden foran både Slesvig og kongeriget. De slesvigske byers forholdsvise tilbagegang fremstår ikke mindre klart, når man rangordner de 20 største byer i det gamle danske monarki efter deres indbyggertal: ${ }^{36}$ 


\begin{tabular}{|c|c|c|c|c|c|c|c|c|}
\hline $\mathrm{Nr}$. & $1801 / 03$ & & $1834 / 35$ & & 1860 & & $1910 / 11$ & \\
\hline 1 & Kobenhavn & 100.975 & Kobenhavn & 119.292 & Kabenhavn & 155.143 & Kobenhavn* & 559.398 \\
\hline 2 & Altona & 23.085 & Altona & 26.393 & Altona & 45.524 & Kiel & 211.627 \\
\hline 3 & Flensborg & 13.109 & Flensborg & 12.438 & Flensborg & 19.682 & Altona & 172.628 \\
\hline 4 & Slesvig & 7.823 & Kiel & 11.622 & Kiel & 17.541 & Århus & 61.755 \\
\hline 5 & Rendsborg & 7.573 & Slesvig & 11.040 & Odense & 14.255 & Flensborg & 60.922 \\
\hline 6 & Kiel & 7.075 & Rendsborg & 9.947 & Slesvig & 12.197 & Odense & 42.237 \\
\hline 7 & Odense & 5.782 & Odense & 8.709 & Ärhus & 11.009 & Wandsbek & 35.212 \\
\hline 8 & Helsingar & 5.282 & Helsingør & 7.122 & Rendsborg & 10.702 & Neumünster & 34.555 \\
\hline 9 & Ålborg & 5.579 & Ålborg & 7.048 & Ålborg & 10.069 & Ålborg & 33.449 \\
\hline 10 & Glückstadt & 5.178 & Ärhus & 6.765 & Randers & 9.725 & Horsens & 23.843 \\
\hline 11 & Randers & 4.562 & Randers & 6.407 & Horsens & 8.980 & Randers & 22.970 \\
\hline 12 & Århus & 4.102 & Glückstadt & 5.988 & Helsinger & 8.442 & Slesvig & 19.908 \\
\hline 13 & Husum & 3.658 & Haderslev & 5.745 & Haderslev & 8.012 & Esbjerg & 18.208 \\
\hline 14 & Fredericia & 3.474 & Itzehoe & 5.495 & Itzehoe & 7.366 & Rendsborg & 17.314 \\
\hline 15 & Haderslev & 3.141 & Heide & 5.135 & Neumü̈nster & 6.803 & Vejle & 17.261 \\
\hline 16 & Preetz & 3.060 & Horsens & 4.846 & Heide & 6.452 & Itzehoe & 16.547 \\
\hline 17 & Egernforde & 2.921 & Preetz & 4.581 & Fredericia & 6.261 & Elmshorn & 14.789 \\
\hline 18 & Aabenraa & 2.834 & Wedel & 4.428 & Wandsbek & 6.001 & Fredericia & 14.228 \\
\hline 19 & Sonderborg & 2.761 & Fredericia & 4.141 & Glückstadt & 5.752 & Kolding & 14.219 \\
\hline 20 & Itzehoe & 2.659 & Egernførde & 3.908 & Svendborg & 5.537 & Helsinger & 13.783 \\
\hline
\end{tabular}

* Inkl, Frederiksberg

I løbet af de 100 år gled Flensborg fra tredje- ned til femtepladsen, mens Slesvig by røg fra fjerde- og helt ned til tolvtepladsen; de øvrige fem slesvigske byer på listen gled helt ud! Det var både kongerigske og holstenske byer, som fortrængte de slesvigske. Nedturen tog især fart efter 1864.

Der er flere forklaringer på de slesvigske byers forholdsvise tilbagegang. For det første synes deres udgangspunkt i 1803 at have været særlig godt, eftersom den slesvigske skibsfart og de slesvigske østkystkøbstæder - frem for alle Flensborg - netop da nød godt af en udpræget højkonjunktur, som til gengæld slog om til dyb krise efter $1807 .{ }^{37}$ For det andet gik \#røskøbing og Marstal ud af de slesvigske byers række i 1864 og Burg på Femern i 1867. For det tredje ramtes de slesvigske byer, navnlig Haderslev og - mere kortvarigt - Flensborg, af grænsedragningen i 1864, der afskar begge byer fra deres handel på kongeriget og Haderslev desuden fra en del af sit nordlige opland. For det fjerde og vigtigste mistede Slesvig i 1864 sin hidtidige 
funktion som bro mellem Holsten og kongeriget og fik i stedet status som den nordligste periferi af det nye Tyskland. Som følge heraf var udvandringen fra Slesvig fra 1860'erne til 1880'erne særdeles kraftig. Den industrialisering, som skulle have trukket landområdernes overskudsbefolkning ind til byerne, manglede simpelthen - undtagen $i$ Flensborg.

Det er hermed antydet, at urbaniseringen kom de slesvigske købstæder og flækker til gode $\mathrm{i}$ vidt forskelligt mål. Nogle var vindere og andre tabere. Per Boje og Ole Hyldtoft benytter i deres artikel Økonomiske, geografiske og demografiske aspekter $\mathrm{i}$ antologien Urbaniseringsprocessen $i$ Norden fra 1977 en inddeling af de danske byer i hovedstaden, landsdelscentre på 30.-100.000 indbyggere, regionale centre på 6.-30.000 indbyggere, oplandsbyer på 3.-6.000 indbyggere og småbyer under 3.000 indbyggere. Med udeladelse af hovedstaden kan de samme begreber overføres på slesvigske forhold. I første omgang undersøges alene de traditionelle købstæders og flækkers udvikling 18031910. Udviklingen indenfor de enkelte kategorier vises i nedenstående fem diagrammer.

Landsdelscenter og regionale centre: Efter kun at have ligget et par tusind indbyggere over Slesvig by i perioden 1835-45 tog Flensborg større afstand fra denne i årene 1855-71 for derefter at stikke endegyldigt af og etablere sig som det gamle hertugdømmes eneste landsdelscenter fra 1880 'erne. Flensborg var med en tredobling af sit indbyggertal i den preussiske tid den eneste by i Slesvig, som havde en tilvækst, der blot nogenlunde kunne matche de største danske provinsbyer. Under Flensborg fandtes i det nye slesvigske byhierarki, som opstod i løbet af århundredet, oprindelig to regionale centre. For den sydlige del var det Slesvig by, som havde en langt mere afdæmpet udvikling end Flensborg, men dog nåede en fordobling i lobet af det 19. århundrede. Udover at være regionalt center var Slesvig by desuden administrativt centrum for hele hertugdømmet. For den nordlige del var Haderslev det regionale center, som imidlertid direkte stagnerede i de første årtier efter $1864 \mathrm{og}$ kun allersidst $\mathrm{i}$ perioden nåede frem til en vækst, der bragte byen op over de 10.000 indbyggere. Fra 1880'erne gjorde Husum sig gældende som et tredje regionalt center på den sydlige del af vestkysten, hvor den var hovedmarkedspladsen for den omfattende kvæghandel. Husums vækst var mere jævn, indtil byen i 1910 nåede tæet ved de 10.000 indbyggere. 
Indbyggertal $i$ de slesvigske landsdels- og regionalcentre

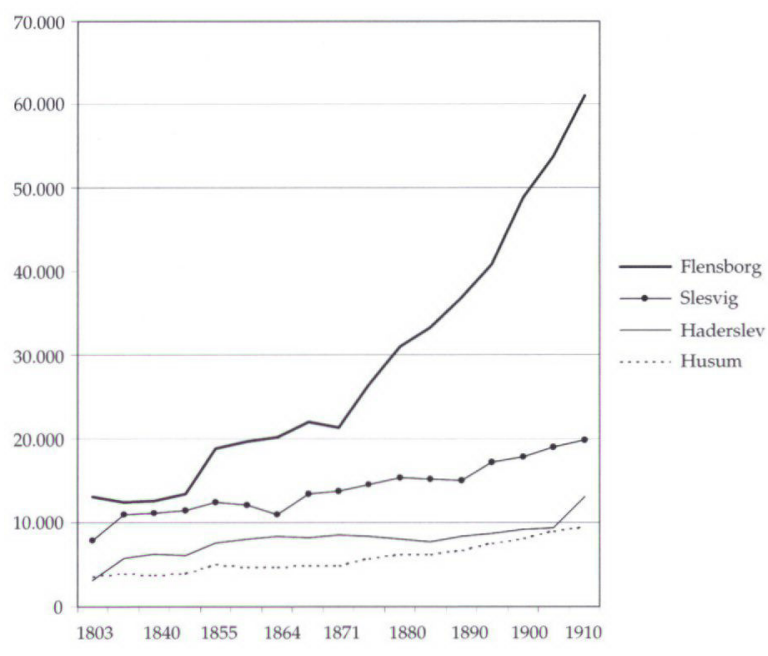

Indbyggertal i de slesvigske oplandsbyer

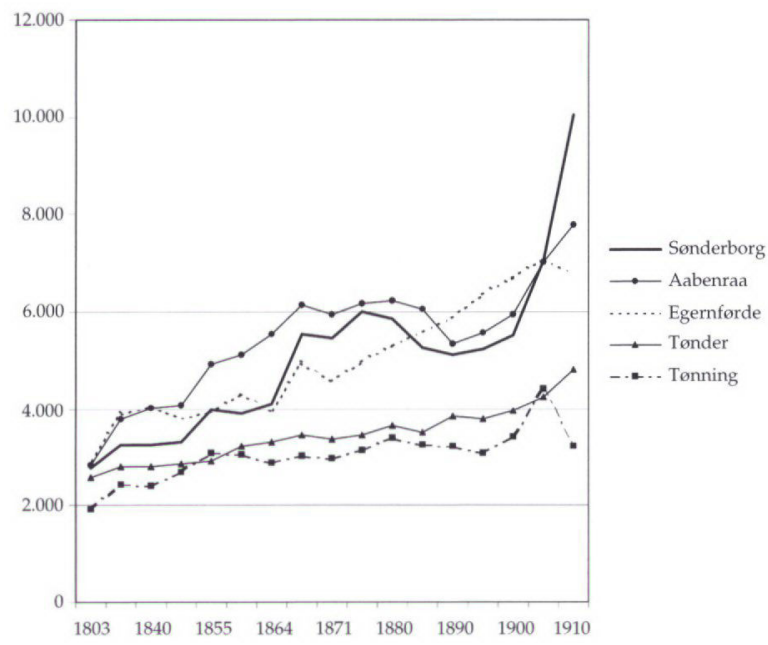

Oplandsbyer: Her lå de tre sidste østkystkøbstæder Aabenraa, Sønderborg og Egernførde groft taget på linje, dog med en mere jævn udvikling i sidstnævnte, mens den for Aabenraa og Sønderborg var mere præget af vækst indtil 1864 og stagnation/tilbagegang frem til 1890; 
til gengæld havde de to nordslesvigske byer en stærk vækst derefter. For Sønderborgs vedkommende skyldtes den oprettelsen af marinestationen i 1907. De to mindre vestkystbyer, Tønder og Tønning, havde en meget afdæmpet udvikling - Tønning oven i købet en tilbagegang 1905-10, hvor alle andre byer havde en stærk tilvækst. Tønning lå lige akkurat over grænsen til de egentlige småbyer.

Småbyer: Ø-købstæderne Ærøskøbing og Burg hørte sammen med de to små købstæder i sydvest, Garding og Frederikstad, til blandt småbyerne. Efter en pæn vækst i første halvdel af 1800-tallet forsvandt de to første ud af det slesvigske bylandskab i 1864/67. Frederikstad var gennemgående præget af en lav og usikker vækst, mens Garding efter en pæn tilvækst stagnerede efter 1880.

Heller ikke i de nordslesvigske flækker var der tale om nævneværdig vækst - bortset fra Marstal, der voksede med 1000 indbyggere, så længe flækken hørte til Slesvig. Christiansfeld lå nærmest helt konstant, mens Augustenborg havde sine op- og nedture, som formentlig navnlig var betinget af hertugernes forsvinden i 1848 og efter 1864 af militærets forbigående tilstedeværelse. Nordborg gik næsten lige så meget tilbage efter 1864, som den forud var gået frem, mens det så noget lysere ud i Løgumkloster. Stærkest var byudviklingen i Højer.

Blandt de sydslesvigske flækker var der mere bevægelse. Kappel hav-

Indbyggertal $i$ smäbyerne - slesvigske købstæder

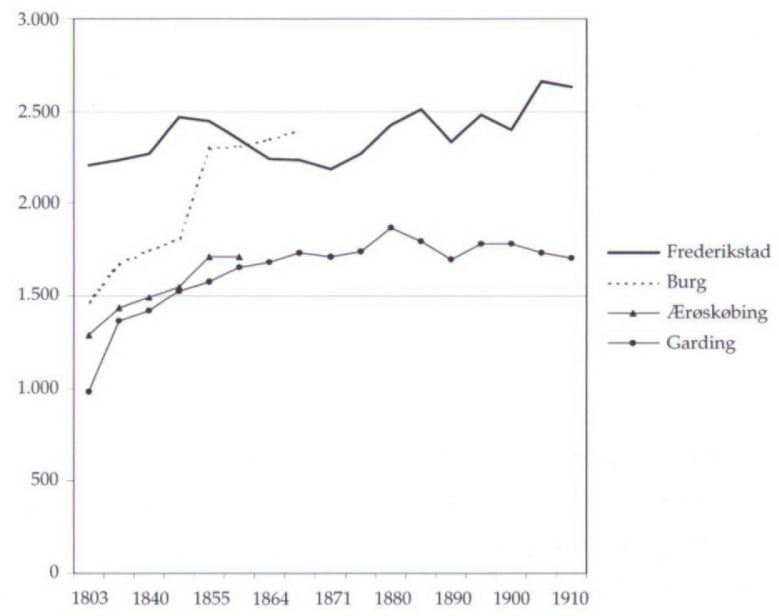


Indbyggertal $i$ smabyerne - nordslesvigske flakker

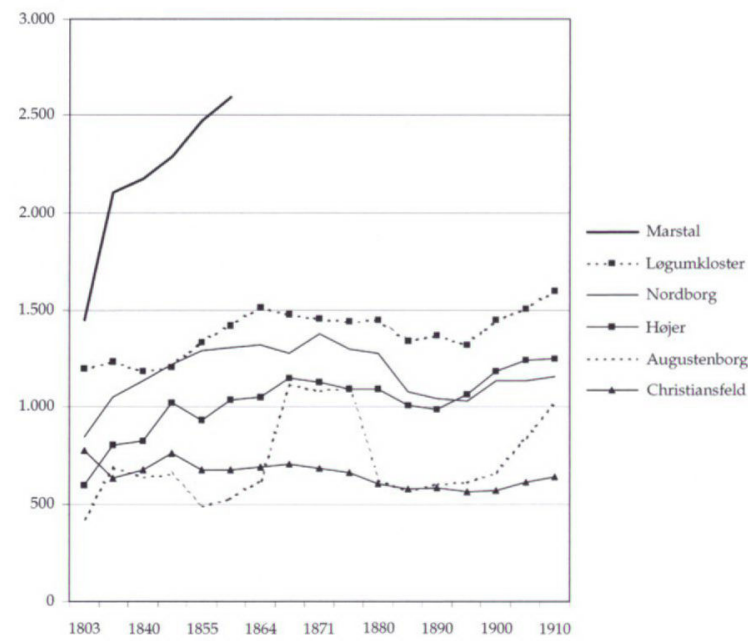

Indbyggertal $i$ småbyerne - sydslesvigske flakker

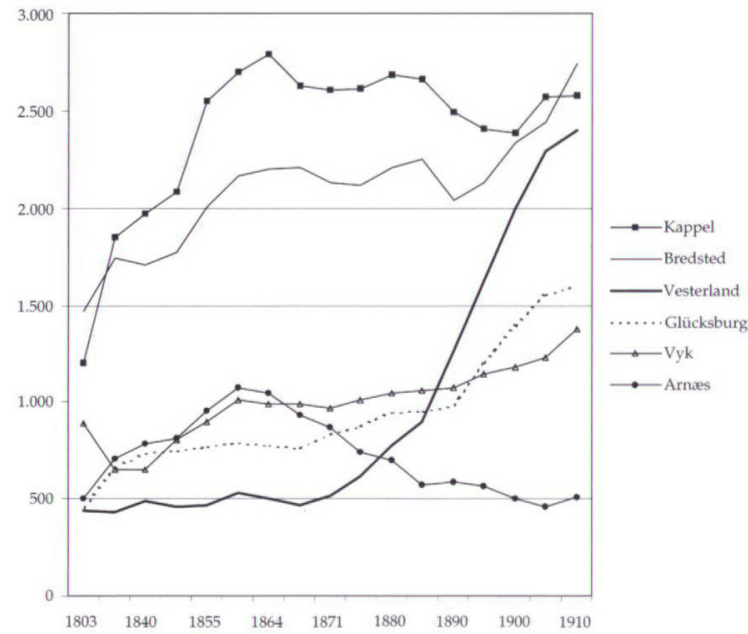

de en stærk vækst indtil 1864, men stagnerede derefter, mens Bredsted og - på et lavere niveau Glücksborg og Vyk - havde et mere jævnt vækstforløb. Himmelstormeren var Vesterland på Sild, der i 1905 gik direkte fra landkommune til købstad. Byens fremvækst og 
stærke ekspansion skyldtes øens etablering som badested efter 1871 . For Arnæs betød tiden efter 1864 ubrudt tilbagegang med en halvering af indbyggertallet.

Stationsbyer: Småbyernes gruppe blev i perioden efter 1864 udvidet med stationsbyerne. For deres vedkommende kan befolkningsudviklingen følges efter indførelsen af de preussiske landkommuner i 1867. Nedenstående tabel bringer befolkningstal for 25 jernbaneknudepunkter, endestationer og andre vigtige stationer udenfor købstæder og flækker i $1910 .^{38}$ Med Rødekro, Bredebro og Sørup som undtagelser er kun stationsbyer med mindst 600 indbyggere taget med, svarende til gruppe $\mathrm{A}$ i den danske stationsbyhistoriker Niels P. Stillings tredeling af stationsbyerne efter størrelse: Gruppe A med over 600 indbyggere, gruppe B med 400-600 og gruppe C med under 400 indbyggere. I gruppe $\mathrm{A}$ fandtes således adskillige stationsbyer, som befolkningsmæssigt lå på linje med de mindste af flækkerne. Det bemærkes, at indbyggertallene gælder for de pågældende preussiske landkommuner, der oftest svarede til et enkelt ejerlav. Det er ikke muligt at udskille den egentlige bymæssige bebyggelse: ${ }^{39}$ 


\begin{tabular}{|c|c|c|c|c|c|}
\hline \multirow[t]{2}{*}{ Stationsby } & \multirow[t]{2}{*}{ Baneforbindelser og disses etableringsår } & \multicolumn{3}{|l|}{ Folketal } & \multirow{2}{*}{$\begin{array}{l}\text { Tilvækst } \\
1867-1910 \\
\end{array}$} \\
\hline & & 1867 & 1895 & 1910 & \\
\hline Sommersted & $\begin{array}{l}\text { Ostlige langdebane 1866, amtsbane } \\
\text { Haderslev-Sommersted-Skodborg } 1905\end{array}$ & 309 & 475 & 693 & $124 \%$ \\
\hline Vojens & $\begin{array}{l}\text { Østlige længdebane } 1866, \text { stikbane til } \\
\text { Haderslev } 1866\end{array}$ & 331 & 574 & 871 & $163^{\prime \prime}$ \\
\hline Rodekro & $\begin{array}{l}\text { Ostlige længdebane } 1864 \text {, stikbane til } \\
\text { Aabenraa } 1868\end{array}$ & \multicolumn{2}{|c|}{ 1880: ca. 50} & ca. 500 & $900^{\circ} \circ$ \\
\hline Tinglev & $\begin{array}{l}\text { Ostlige længdebane } 1864 \text {, stikbaner til Tonder } \\
1867 \text { og Senderborg } 1901\end{array}$ & $321^{*}$ & 513 & 864 & $169 \% * *$ \\
\hline Jybæk & $\begin{array}{l}\text { Ostlige længdebane og stikbane til Husum } \\
1869\end{array}$ & 298 & 454 & 713 & $139^{\circ} \circ$ \\
\hline Owschlag & $\begin{array}{l}\text { Slesvig-Rendsborg } 1854 / 58 \text { (fra } 1869 \text { ustlige } \\
\text { længdebane), amtsbane Owschlag-Egernfurde } \\
1904\end{array}$ & 494 & 577 & 637 & $29^{\circ} \circ$ \\
\hline Sorup & $\begin{array}{l}\text { Flensborg-Kiel 1881, amtsbane Satrup-Sorup- } \\
\text { Rundtoft } 1902\end{array}$ & 219 & 320 & 581 & $165^{\circ} \circ$ \\
\hline Sonder Brarup & $\begin{array}{l}\text { Flensborg-Kiel 1881, amtsbane Slesvig-Sonder } \\
\text { Brarup } 1883 \text { og Sonder Brarup-Kappel } 1904\end{array}$ & 621 & 1116 & 1959 & $215^{\prime \prime \prime}$ \\
\hline Gettorf & Flensborg-Kiel 1881 & $1220^{*}$ & 1582 & 1671 & $37^{\prime \prime} \%$ \\
\hline Hviding & Vestkystbanen 1887 & 584 & 597 & 676 & $16^{\prime \prime} 0$ \\
\hline Skærbæk & $\begin{array}{l}\text { Vestkystbanen 1887, amtsbane Skærbæk- } \\
\text { Amum } 1911\end{array}$ & $867^{*}$ & 1064 & 1453 & $68^{\prime \prime \prime}$ \\
\hline Brede/Bredebro & $\begin{array}{l}\text { Vestkystbanen 1887, stikbane til Løgumkloster } \\
1888\end{array}$ & 209 & 301 & 348 & $67^{\prime \prime \prime}$ \\
\hline Nibel & $\begin{array}{l}\text { Vestkystbanen 1887, amtsbane Nibol-Dagebol } \\
1895\end{array}$ & 1650 & 1848 & 2038 & $24 " \prime$ \\
\hline Lindholm & Vestkystbanen 1887 , Lindholm-Flensborg 1888 & 1200 & 1108 & 1049 & $-13^{\prime \prime}$ \\
\hline Læk & Lindholm-Flensborg 1888 & 1071 & 1189 & 1269 & $18^{\prime \prime \prime}$ \\
\hline Grásten & $\begin{array}{l}\text { Tinglev/Flensborg-Torsbol-Sonderborg 1901, } \\
\text { amtsbane Aabenraa-Grásten } 1899\end{array}$ & 772 & 1141 & 1501 & $94^{\prime \prime} "$ \\
\hline Vester Sottrup & $\begin{array}{l}\text { Tinglev/Flensborg-Trrsbol-Sonderborg } 1901, \\
\text { Vester Sottrup-Skelde } 1910\end{array}$ & 771 & 803 & 1008 & $31^{\prime \prime \prime}$ \\
\hline Broager & Vester-Sottrup-Skelde 1910 & 468 & 1073 & 1223 & $26^{\prime \prime} 0$ \\
\hline Skelde & Vester Sottrup-Skelde 1910 & 619 & 592 & 679 & $10^{\prime \prime} \%$ \\
\hline Nørre Stapel & $\begin{array}{l}\text { Husum-Rendsborg 1910, amtsbane } \\
\text { Frederikstad-Slesvig 1905 }\end{array}$ & 711 & 693 & 772 & $9^{\prime \prime \prime}$ \\
\hline Rodding & $\begin{array}{l}\text { Amtsbane Haderslev-Ustrup-Vojens-Gram } \\
\text { Rrdding } 1899\end{array}$ & 885 & 429 & 1320 & $4 y^{\prime \prime \prime}$ \\
\hline Gram & $\begin{array}{l}\text { Amtsbaner Haderslev-Ustrup-Vojens-Gram } \\
\text { Rodding } 1899 \text { og Arnum-Gram } 1910\end{array}$ & 552 & 422 & 801 & $45^{\prime \prime \prime}$ \\
\hline Toftlund & $\begin{array}{l}\text { Amtsbane Ustrup-Over Jerstal-Toftlund } 1904 \\
\text { og Toftlund-Arnum } 1910\end{array}$ & 455 & 784 & 1122 & $147 \%$ \\
\hline Skodborg & $\begin{array}{l}\text { Amtsbane Haderslev-Sommersted-Skodborg } \\
1905\end{array}$ & 1130 & 1129 & 1487 & $32 \cdots+$ \\
\hline Satrup & $\begin{array}{l}\text { Amtsbaner Flensborg-Satrup 1901, Satrup- } \\
\text { Sorup-Rundtoft } 1902 \text { og Satrup-Slesvig } 1904\end{array}$ & 384 & 537 & 816 & $113 \% * *$ \\
\hline
\end{tabular}

* 1871

** For Tinglev og Satrup skyldtes en mindre del af vaksten indlemmede nabokommuner eller dele heraf; for Skodborgs vedkommende havde dette sturre betydning. 
Samlet voksede befolkningen i de større stationsbyer fra knap 17.000 i 1867 til godt 26.000 i 1910 eller med 57\%. Denne tilvækst skal ses på baggrund af, at udviklingen i landbefolkningen i den preussiske tid generelt var meget afdæmpet og i de første årtier efter 1864 præget af direkte tilbagegang. Desto mere springer det i øjnene, at de større stationsbyer på den østlige længdebane (med undtagelse af Rødekro) og banen Flensborg-Kiel havde en pæn vækst allerede før 1895. Det samme gælder de større stationsbyer på vestbanen, i Sydslesvig dog i mindre grad på grund af det ekstensive kvægfedningslandbrug $\mathrm{i}$ marsken. Bemærkelsesværdig er væksten i Toftlund, Gråsten, Broager og Satrup, der var i gang, før byerne overhovedet fik en station - en bekræftelse på, at det ikke så meget var baneforbindelsen i sig selv som intensiveringen i oplandets landbrug (og for Broagers vedkommende teglværksindustrien), der skabte grundlaget for stationsbyerne.

\section{Byernes geografiske udvidelse}

En del af væksten i de større byers indbyggertal skyldtes indlemmelse af nabokommuner, enten helt eller delvist. Sådanne udvidelser af byernes areal $\mathrm{i}$ takt med bebyggelsens ekspansion ud over den gamle bygrænse var en naturlig del af urbaniseringsprocessen, og det vil derfor ikke være rigtigt - og næppe heller muligt - at isolere og udrense denne faktors betydning for befolkningstilvæksten.

Før 1867 skete udvidelser kun i få tilfælde og tildels efter meget lange overvejelser. Det drejede sig mest om indlemmelse af de såkaldte slotsgrunde, d.v.s. de gamle byslottes og dermed amtsadministrationernes territorier, der endnu hørte amterne og mere eller mindre henlå som enklaver i byterritorierne. I preussisk tid skete indlemmelserne især i 1870'erne og efter år $1900 .^{40}$

I Haderslev blev Slotsgrunden indlemmet i 1834, efter at magistraten allerede i 1799 havde overbevist Tyske Kancelli om det fornuftige heri. En kommission blev nedsat, men dens arbejde blev saboteret af Slotsgrundens beboere og vistnok også af amtmanden, under hvem Slotsgrunden hørte. Den slesvigske administrations manglende evne eller vilje til at skære igennem overfor særinteresser viste sig her ved, at der måtte nedsættes hele tre kommissioner, før indlemmelsen endelig kom på plads! ${ }^{41} \mathrm{Og}$ så var militærets arealer på Naffet endog undtaget fra indlemmelsen. Disse ubebyggede arealer fik købstaden først 
1842/43 efter militærets bortflytning; til gengæld blev de af stor betydning for byens vækst i 1850 'erne. Den næste indlemmelse skete først i 1910, hvor hele Sønder Otting kommune samt beboede grundstykker fra Ladegård I og Gl. Haderslev kommuner blev indlemmet. Sidstnævnte afgav yderligere areal til byen i 1912 .

I Aabenraa blev ønsket om en indlemmelse af Slotsgade fremført over for kancelliet af bystyret i 1839, men den kongelige resolution fra 1843 bestemte, at indlemmelsen først skulle ske i 1861. Og så måtte Aabenraa pænt vente så længe, skønt det efterhånden kneb alvorligt med ledige arealer i købstaden. ${ }^{42}$ Endnu længere tid gik før den næste indlemmelse, der omfattede Kolstrup kommune i 1901. I Sønderborg købte bystyret i 1860 Sønderborg Ladegård, men uden at ladegården ved denne lejlighed blev indlemmet $\mathrm{i}$ købstaden. Sønderborg Slot lå også fortsat på amtsgrund. Bystyret fremsatte ønsket om en forøgelse af byens territorium bl.a. med disse arealer i 1869. Den preussiske administration var hurtigere end den slesvigske, og i 1874 indlemmedes ikke alene slottet og ladegården, men også dele af Sundsmark, Ulkebøl og Dybbøl kommuner i købstaden. Dermed fik Sønderborg gode udvidelsesmuligheder årtier frem. ${ }^{43}$ I Tonder forblev Slots- og Frigrunden amtets enklave i købstaden helt indtil 1933, og der fandt heller ingen andre indlemmelser sted for 1914. ${ }^{44}$

I Flensborg blev en udvidelse af købstaden med de østlige forstæder Nørre og Sønder Sct. Jørgen foregrebet, da disse territorier i $1854 \mathrm{blev}$ underlagt byens retsvæsen og i 1856 dens administration. ${ }^{45}$ Som i Sønderborg skete den endelige indlemmelse først i preussisk tid, i 1874. Året efter indlemmedes desuden Hulvejene mod øst, Fiskergård og Duborg. De to sidste steder var henholdsvis amtsforvaltningens og det gamle slots territorium. I takt med byens vækst indlemmedes desuden Jørgensgård i 1900, Klus i 1909 og Fruerlund, Engelsby, Tved og Tvedskov (med Mørvig) i $1910 .{ }^{46}$ Derimod er forstadsbebyggelsen på Harreslev Mark forblevet en del af Harreslev kommune.

I Slesvig blev Gottorp slot og slotsgrunden indlemmet $\mathrm{i}$ byen $\mathrm{i}$ $1858 .{ }^{47} \mathrm{I}$ preussisk tid forøgedes byens areal med dele af Skovby kommune i 1873, 1879 og 1910. I Husum var beboerne på slotsgrunden allerede i 1823 blevet forenet med Husum by for så vidt angår kirkeog fattigvæsen. ${ }^{48}$ Her indlemmedes desuden nogle smågrunde fra Parrenkoog i 1873 og Osterhusum og Nordhusum samt Arlevad Grund i 1875. I Tønning var jurisdiktionen over Ejderen og de ved Ejderen beliggende losse- og ladepladser blevet overdraget til byen $\mathrm{i}$ 

helt ud. Systemet var også temmelig stivnet. Der var ikke i Slesvig byer, der sprængte rangordenen så iøjnefaldende som Kiel gjorde $\mathbf{i}$ Holsten og Esbjerg i Danmark. Bortset fra tabet af Ærøskøbing og Marstal i 1864 og Burg i 1867 var byerne gennem hele perioden de samme, når den juridiske definition lægges til grund. De sydslesvigske flækkers forfremmelse til købstæder var udelukkende nominel. Eneste slesvigske "himmelstormer " var karakteristisk nok badebyen Vesterland, der blev købstad i 1905, men knap var nået op på 2.500 indbyggere i 1910 - langt fra vestjyske paralleller som Esbjerg og Herning med købstadsrettigheder fra 1899 og 1913.

Set fra et rent slesvigsk udsigtspunkt kunne forandringerne være nok så gennemgribende endda. Det slesvigske byhierarki blev mere udpræget i løbet af 1800-tallet, navnlig efter 1864. I toppen tog Flensborg definitivt afstand til de andre købstæder og etablerede sig som det gamle hertugdømmes eneste landsdelscenter. Kun her fandtes tilstrækkelig kritisk masse af kapital, fremsyn og arbejdskraft til et klassisk industrielt gennembrud og samtidig til en stærk ekspansion indenfor søfarten, hvortil kom fordelen for engroshandelen ved byens placering midt $\mathrm{i}$ hertugdømmet. Flensborg nød godt af at være regeringsby fra 1850, men led ikke nævneværdig skade ved provinsadministrationens tilbageflytning til Slesvig efter 1864. Bortset fra en minimal tilbagegang mellem 1867 og 1871 havde Flensborg en ubrudt vækst fra 1835 til 1910.

Omvendt bidrog Slesvigs genvundne status som regeringsby sammen med en vis industriel udvikling til at fastholde denne by på andenpladsen blandt hertugdømmets byer. Slesvig var tillige et regionalt center for hertugdømmets sydlige del, ligesom Haderslev var for den nordlige og som Husum med tiden blev for den sydvestlige. Oplandsbyer var Aabenraa, Sønderborg og Egernførde på østkysten samt Tønder og Tønning på vestkysten. De fleste af disse byer oplevede en kortere eller længere periode med stagnation, typisk i 1880 'erne; det gjaldt navnlig de nordslesvigske, der til gengæld kom stærkt igen efter århundredskiftet. Blandt de regionale centre og oplandsbyerne var der som helhed tale om en voksende tendens. Blandt småbyerne - de små købstæder Frederikstad og Garding i sydvest samt flækkerne - var billedet mere broget med både vindere og tabere - mest det sidste.

Imidlertid fik klassen af småbyer en tiltrængt forstærkning ved opkomsten af 20-30 større stationsbyer. Analysen af de slesvigske cen- 
tralsteder 1800 og 1860 viste, at der allerede i første halvdel af 1800tallet var et stigende antal bebyggelser, der kunne karakteriseres som rurale byer uden formelle byprivilegier. Denne tendens fik takket være landbefolkningens øgede velstand og et mere intensivt landbrug efter 1864 et kraftigt skub fremad med jernbanerne som en betydningsfuld katalysator for lokaliseringen af de nye rurale byer.

Det var således $\mathrm{i}$ toppen og $\mathrm{i}$ bunden af byhierarkiet, de største forandringer skete.

Den juridiske og statistiske tilgang tager imidlertid ikke tilstrækkelig højde for byernes stigende betydning for hele den slesvigske befolkning. Administrationens, sundhedsvæsenets og uddannelsesinstitutionernes vækst, infrastrukturens udbygning, pressens fremvækst og inddragelsen af den brede befolkning i den politiske proces betød, at slesvigerne på landet fik langt flere berøringsflader til deres nærmeste købstad. Stationsbyerne bragte $\mathrm{i}$ mindre format bylivet på nærmere hold. Bykulturen blev i højere grad normsættende også for landbefolkningen. Det blev stadig sværere at unddrage sig dens indflydelse - hvis det da overhovedet var, hvad man ville.

\section{LITTERATUR}

700 Jahre Stadt Eckernförde. Eckernförde 2001.

Asmus, Walter; Kunz, Andreas og Momsen, Ingwer E.: Atlas zur Verkehrsgeschichte Schleswig-Holsteins im 19. Jahrhundert. Neumünster 1995.

Baggesen, August von: Der dänische Staat. Kopenhagen 1847.

Beiträge zur historischen Statistik Schleswig-Holsteins. Kiel 1967.

Bergsøe, A. F.: Den danske Stats Statistik, I. Kbh. 1844.

Boje, Per og Hyldtoft, Ole: Danmark. Økonomiske, geografiske og demografiske aspekter (Urbaniseringsprocessen i Norden, 3. Industrialiseringens første fase. Det XVII. nordiske historikermøte. Trondheim 1977, s. 178244).

Christiansen, Theo: Schleswig 18361945. Schleswig 1973.

Chronologische Sammlung der ... Ver- ordnungen und Verfügungen für die Herzogthümer Schleswig und Holstein. 1831-1850.

Chronologisk Samling af de i Aaret ... emanerede Forordninger, Rescripter etc. for Hertugdømmet Slesvig. 18501864.

Die Bevölkerung der Gemeinden in Schleswig-Holstein 1867-1970. Kiel 1972.

Falck, Niels Nic.: Handbuch des Schleswig-Holsteinischen Privatrechts, I. Altona 1825.

Fangel, Henrik: Haderslev bys historie 1800-1945. I. Haderslev 1975.

Fangel, Henrik: Haderslev bys historie 1864-1920 (Haderslev bys historie 1800-1945, bind 2). Haderslev og Aabenraa 1996.

Fangel, Henrik: Rødekro før 1914. En oversigt. Særtryk af Rødekro skole 1913-88. Aabenraa 1988. 
Flensborg bys historie II. København 1955.

Flensburg. Geschichte einer Grenzstadt. Flensburg 1966.

Furdal, Kim: Flækkekommuner (Peter Fransen m.fl:: Harmonisering eller særordning. Aabenraa 2002, s. 335381).

Geschichte Husums. Von den Anfängen bis zur Gegenwart. Husum 2003.

Geschichte Schleswig-Holsteins Band 8, Teil 1, Lieferung 1-2. Neumünster 1966-2006.

Gesetz-Sammlung für die Königlichen Preussischen Staaten 1867.

Greve, Klaus: Zentrale Orte im Herzogtum Schleswig um 1800 (Zeitschrift der Gesellschaft für schleswig-holsteinische Geschichte Band 106, 1981, s. 89-115).

Greve, Klaus: Zentrale Orte im Herzogtum Schleswig 1860. Neumünster 1987.

Gudme, A. C.: Tabellarische Uebersicht des Areals und der Bevölkerung der beiden Herzogthümer Schleswig und Holstein (Kieler Blätter III, Kiel 1816, s. 413-417).

Haase, L.: Die Gemeindeverfassungsgesetze für die Provinz Schleswig-Holstein. Berlin 1888.

Henningsen, Lars N.: Byerne i Slesvig ca. 1700-1830 - en variant af dansk købstadshistorie (Sønderjyske årbøger 2006, s. 37-66).

Historischer Atlas Schleswig-Holstein. Vom Mittelalter bis 1867. Neumünster 2004.

Historischer Atlas Schleswig-Holstein 1867 bis 1945 . Neumünster 2001.

Jessen, Franz von: Haandbog i det nordslesvigske Spørgsmaals Historie. Kbh. 1901.

Jessen, Franz von: Haandbog i det slesvigske Sporgsmaals Historie, 1. Kbh. 1938.

Kaadtmann, Christian: Stationsbyer i Sonderjylland - Toftlund og Hjordkær. Aabenraa 1985.

Kaadtmann, Christian: Skærbæk - en sonderjysk stationsby og dens naboer (Nyt fra Stationsbyen 8, 1985, s. 3651).

Momsen, Ingwer E.: Statistik des schleswig-holsteinischen Schiffsbe- standes 1745-1865 (Rundbrief des Arbeitskreises für Wirtschafts- und Sozialgeschichte Schleswig-Holsteins Nr. 66, s. 37-51 og Nr. 67, s. 23-47).

Müller, Manfred J. og Riecken, Guntram: Stadtlandschaften in Schleswig-Holstein. Neumünster 1990.

Nielsen, Jens H.: Tinglev - et grænsesogn. Tinglev u.år.

Nielsen, Leif Hansen: Ad Industriens Vej ... Studier i den slesvig-holstenske industri 1864-1914 med særlig henblik på udviklingen i Nordslesvig. Aabenraa 2007.

Oldekop, Henning: Topographie des Herzogtums Schleswig. Kiel 1906.

Provinzial-Handbuch für SchleswigHolstein 1871. Kiel 1871.

Pust, Dieter: 125 Jahre schleswig-holsteinische Städteordnung - 60 Jahre Stadt Arnis - Ein Beitrag zur Fleckensverfassung in SchleswigHolstein (Die Heimat 1994, s. 116122).

Pust, Dieter: 125 Jahre Städteordnung in Schleswig-Holstein. Das Echo auf die Allgemeine Städteordnung vom 18. Oktober 1848 (Die Heimat 1973, s. 296-299).

Pust, Dieter: Die ersten Eckernförder Kommunalwahlen $\quad$ 1832-1848 (700 Jahre Stadt Eckernförde, Eckernförde 2001, s. 231-252).

Pust, Dieter: Politische Sozialgeschichte der Stadt Flensburg. Flensburg 1975.

Schröder, Johs. von: Hertugdømmet Slesvigs Topographi. 2. udg. Oldenborg i Holsteen 1854.

Schultz Hansen, Hans: Den tidlige industrialisering $i$ hertugdømmet Slesvig 1830-1864 (Sønderjyske årbøger 2006, s. 141-168).

Schultz Hansen, Hans: Det sønderjyske landbrugs historie 1830-1993, Aabenraa 1994.

Statistisk Tabelværk. Tredie Række, første Bind, indeholdende Tabeller over Folkemængden i Kongeriget Danmark, Hertugdømmet Slesvig, Hertugdømmet Holsteen og Hertugdømmet Lauenborg, efter Alder, Kjøn og ægteskabelig Stilling samt efter Næringsvei og Stilling, den 1ste Februar 1860. København 1863.

Statistisk Årbog 1913. Kbh. 1913. 
Sollinge, Jette D. og Thomsen, Niels: De danske aviser 1634-1989. 1-2. 16341847. Odense 1989.

Sønderborg bys historie. Udgivet af et udvalg ved Holger Hjelholt. I-II. Sønderborg 1960-1966.

Senderborg i 750 år - tværsnit og perspektiver. Red. af Inge Adriansen og Peter Dragsbo. Sonderborg 2005.

Sørensen, H. E.: Handel og håndværk i Skærbæk gennem 100 ăr. Skærbæk 1981.

Trap, J. P.: Statistisk-topographisk Beskrivelse af Hertugdømmet Slesvig. I-II. Kebenhavn 1864.

Trap, J. P.: Danmark, X,1: Haderslev amt. X,2: Tonder amt. X,3: AabenraaSønderborg amt. København 19651967.

Tonder gennem tiderne. Red. af $M$. Mackeprang. Tonder 1943-44.

Tönning im Wandel der Zeiten. Husum 1990.

Vorläufige Ergebnisse der Volkszählung vom 1. Dezember 1910 im Königreiche Preussen. Berlin 1911.

Åbenrå Bys Historie. Redigeret af Johan Hvidtfeldt og Peter Kr. Iversen. II-III. Aabenraa 1967-1974.

\section{NOTER OG HENVISNINGER}

1. Om købstæders og flækkers juridiske status $\mathrm{i}$ den slesvigske adminstration indtil 1864, se Falck s. 24-26, 32-34. For tiden efter 1867 se Geschichte Schleswig-Holsteins Band 8, Teil 1 s. 38f, 42, 59, 64, 7783, 109-111 (Oswald Hauser). Om byerne i Sydslesvig, se Müller og Riecken s. 211-222. Om flækkerne endvidere Furdal samt Pust: 125 Jahre schleswig-holsteinische Städteordnung.

2. Chronologische Sammlung $1808 \mathrm{~s}$. 228 og 1850 s. 141.

3. Bilag B til kredsforordningen af 22 . september 1867, Gesetzsammlung 1867 s. $1601 f$.

4. Marstal regnedes dog som flække også før 1861, jfr. von Baggesen s. $250 \mathrm{og}$ von Schröder s. $315 \mathrm{f}$.
5. Opregningen af flækker følger Furdal s. 338, der med tilføjelse af Marstal følger Pust: 125 Jahre schleswig-holsteinische Städteordnung s. 119.

6. Von Baggesen s. 214, 222f, 229f, 232, 253, 257; Falck s. 32-34; Schröder s. 174, 355, 453; Trap: Slesvig s. 244, 294, 363, 676 .

7. Pust: Die ersten Eckernförder Kommunalwahlen.

8. Pust: Politische Sozialgeschichte, især s. 108-112. Om Haderslev tillige Fangel: Haderslev I s. 320-326.

9. Pust: 125 Jahre Städteordnung. Chronologische Sammlung $1848 \mathrm{~s}$. 406-458.

10. Se herom Geschichte SchleswigHolsteins Band 8, Teil 1, s. 77-83. Lovens tekst med kommentarer hos Haase s. 26-76.

11. Pust: 125 Jahre schleswig-holsteinische Städteordnung s. 119 samt Geschichte Schleswig-Holsteins Band 8, Teil 1 s. 81.

12. Pust: Politische Sozialgeschichte, især s. 128-130, 159.

13. Geschichte Husums s. 181f.

14. Fangel: Haderslev I s. 86.

15. Sønderborg i 750 år s. 151.

16. Greve: Zentrale Orte im Herzogtum Schleswig um 1800, samme: Zentrale Orte im Herzogtum Schleswig 1860. Bemærk, at Greves undersøgelser ikke omfatter Ærø og Femern og omkr. år 1800 ej heller Vesterhavsøerne.

17. Se herom Kaadtmann: Stationsbyer i Sønderjylland og samme: Skærbæk. Om Skærbæk endvidere H. E. Sørensen. Rødekro behandles af Fangel: Rødekro for 1914. Om Tinglev, se Jens $H$. Nielsen.

18. Oldekop s. I 39, II 49, VI 88 f og 103f, VIII $107 \mathrm{f}$.

19. Se herom Asmus, Kunz og Momsen, især side 36 og $73 f$.

20. Schultz Hansen: Det sønderjyske landbrugs historie $1830-1993$ s. 101208.

21. Eks. fra Oldekop s. VI $95 \mathrm{f}$ og 103f, VIII $56 \mathrm{f}$ og $107 \mathrm{f}$.

22. Desuden var Arnum et knudepunkt for amtsbanerne i Haderslev Vesteramt, men da byen ikke ud- 
gjorde en selvstændig kommune, kendes dens befolkningstal og -udvikling ikke.

23. Se Historischer Atlas SchleswigHolstein 1867 bis 1945 s. 27-29.

24. Se nedenstående tabel over de større stationsbyers befolkningsudvikling.

25. Sst.

26. Det følgende hviler på forskellige årgange af Hof- og Statskalenderen samt Provinzialhandbuch für Schleswig-Holstein. Endvidere Trap: Slesvig I, Alm. del s. 37-85 og Oldekops omtaler af de enkelte byer. Endvidere Flensburg. Geschichte einer Grenzstadt s. 319f. Christiansen s. 35, 44f, 107f, 140.

27. Om militærets placering, se forskellige årgange af Hof- og Statskalenderen og Provinzialhandbuch für Schleswig-Holstein. Desuden Geschichte Schleswig-Holsteins Band 8, Teil 1 s. 146 og Historischer Atlas Schleswig-Holstein 1867 bis 1945 s. 154. Endvidere omtaler af de enkelte byer hos Trap: Slesvig og Oldekop samt Christiansen s. 94f, 109111; Flensburg. Geschichte einer Grenzstadt s. 320, 376, 383, 386f; Fangel: Haderslev I s. $135 \mathrm{f}$ og II s. 59-64; Åbenrå bys historie III s. 10f; Sønderborg bys historie II s. 28-30, $40-42,53$.

28. Se herom Historischer Atlas Schleswig-Holstein Vom Mittelalter bis 1867 , s. $117-120$ og samme $1867-$ 1945 s. $133-140$.

29. Se herom Søllinge og Thomsen.

30. Historischer Atlas Schleswig-Holsten 1867 bis 1945 s. 128.

31. Ingwer E. Momsen: Statistik. Atlas zur Verkehrsgeschichte SchleswigHolsteins s. 34 .

32. Schultz Hansen: Den tidlige industrialisering, jfr. fortegnelsen over fabrikslister s. 165f. Leif Hansen Nielsen, tabel A,6 s. 304 ff. Om Flensborgs erhvervsudvikling 18641914 , se Flensburg. Geschichte einer Grenzstadt s. 356-370.

33. Hovedkilden til de slesvigske krbstæders og flækkers folketal er Beiträge zur historischen Statistik s.
12-15. Haderslev 1803 dog Fangel: Haderslev I s. 18. Flækker 1803: Skønnede tal hos Gudme. Nordslesvigske flækker: Von Schröder s. XXIV, Trap: Slesvig I s. 17f, von Jessen: Haandbog i det nordslesvigske Spørgsmaals Historie s. 283 og samme: Haandbog i det slesvigske Spørgsmaals Historie I s. 169.

34. Jfr. Boje og Hyldtoft s. 182.

35. Kongeriget: Statistisk Årbog $1913 \mathrm{~s}$. 3; Slesvig: Jfr. note 33; Holsten 1803: Gudme; 1860: Statistisk Tabelværk 3,1 s. II, IV, VI; 1910: Vorläufige Ergebnisse s. 34-36.

36. Statistisk Årbog 1913 s. 4-7 (kongeriget 1801 og 1911); Statistisk Tabelværk 3,1 s. IIIf (kongeriget 1860); Beiträge zur historischen Statistik s. 12-15 (hertugdømmerne 1803, 1860 , 1910). Haderslev 1803 dog Fangel: Haderslev I s. 18. Bergsøe s. 405-409 (1834/35).

37. Henningsen s. 41, 61 .

38. Som udgangspunkt drejer det sig om byer, der på kortet i Atlas zur Verkehrsgeschichte s. 39 er benævnt som "jernbaneknudepunkt, vigtig station «. Dog er yderligere et par store stationsbyer frjet til listen: Toftlund, Broager, Gettorf og Læk.

39. Die Bevölkerung der Gemeinden. De nordslesvigske byer 1867: Provinzial-Handbuch für SchleswigHolstein 1871. Rødekro: Fangel: Rødekro.

40. M.h.t. indlemmelser efter 1867 henvises generelt til: Die Bevölkerung der Gemeinden

41. Fangel: Haderslev I s. 53-55.

42. Åbenrå bys historie II s. $201 \mathrm{f}$.

43. Sønderborg bys historie I s. 296, 301 og II s. 18f. Trap: Slesvig II s. 383 , 387.

44. Trap: Danmark X.2 s. 504.

45. Trap: Slesvig II, s. 441.

46. Flensburg. Geschichte einer Grenzstadt s. $375 f, 382$.

47. Chronologisk Samling 1858 s. $177 f$.

48. "Parochial- und Armenverhältnisse«, jfr. Chronologische Sammlung 1823 s. 260.

49. Chronologische Sammlung 1829 s. 280 og 1860, s. 385. 